\title{
İSLAM-OSMANLI EŞYA HUKUKUNDA MÜŞTEREK MALIN TAKSIMI*
}

Arş. Gör. Naci ÇEVİK**

\section{ÖZET}

İslam-Osmanlı eşya hukukunda mülkiyeti kazanma yollarından biriyle ya da en az iki malın ayrılması mümkün olmayacak bir şekilde birbirine karışması suretiyle meydana gelen müşterek mülkiyet, belli bir mal varlığı üzerinde birden fazla kişinin mülkiyet hakkına sahip olmaları anlamına gelmektedir. Bu kapsamda müşterek olarak bir mala sahip olan pay sahipleri o malın belli bir bölümü üzerinde hisseleri oranında malik olmayıp, pay sahiplerinin mülkiyet hakkı malın tamamı üzerinde kendi hissesi oranındadır. Müşterek mülkiyeti sona erdiren sebepler ise söz konusu malın yok olması, istimlâk edilmesi, cebri satışı ya da malın fiziki yapısının veya menfaatlerinin taksim edilmesidir. Dolayısıyla müşterek mülkiyeti sona erdiren sebeplerden taksimin eşyanın fiziki yapısının paylaştırılması ve bu eşyadan elde edilen menfaatlerin bölüştürülmesi şeklinde ikiye ayrllarak incelenmesi mümkündür. Öte yandan müşterek malın taksim edilebilmesi için bölünebilir olması ve taksim işlemi sırasında pay sahiplerinin mülkiyetinde olması gerekmektedir. Keza usulüne uygun ve adil olarak yapılan taksim işlemi taraflar açısından bağlayıcı nitelikte olup, bundan rücu etmek mümkün değildir.

Literatürde her ne kadar İslam-Osmanlı eşya hukukunda müşterek malın paylaştırılması hususunda fazlaca bir çalışma olmasa da ilgi çekici bir kısım çalışma bulunmaktadır. Bununla birlikte bu çalışmalarda konu teorik açıdan İslam hukuku çerçevesinde ele alınıp incelenmiştir. Bu çalışmayı öncekilerden farklı kılan husus ise konuyu İslam hukuku hükümleri çerçevesinde ele alıp incelemenin yanı sıra Osmanlı uygulamasına da yer vermesidir. Bu sebeple çalışmamızda müşterek malın taksimi hususunu bütüncül bir şekilde ele alıp konuya ilişkin İslam hukuku teorisi incelendikten sonra Osmanlı uygulamasından bazı örnekler verilmiştir.

Anahtar Kelimeler: Müşterek Mal, Müşterek Mülkiyet, Malik, Taksim, Hisse.

DOI: 10.33432/ybuhukuk.695846 - Geliş Tarihi: 28.02.2020 - Kabul Tarihi: 16.10.2020.

** Ondokuz Mayıs Üniversitesi Ali Fuad Başgil Hukuk Fakültesi, Hukuk Tarihi Anabilim Dalı, nacicevik@gmail.com, ORCID: 0000-0002-1758-2276. 


\title{
DISTRIBUTION OF JOINT GOODS IN THE ISLAMIC-OTTOMAN THINGS LAW
}

\begin{abstract}
Joint ownership, which occurs in one of the ways of gaining ownership in Islamic-Ottoman property law or by mixing at least two properties in a way that cannot be separated, means that more than one person has the right to property on a certain property. In this context, shareholders who have a jointly owned property do not own a certain portion of that property in proportion to their shares, and the ownership right of the shareholders is in proportion of their shares over the entire property. The reasons that terminate joint ownership are the disappearance, expropriation, forced sale or distribution of the physical structure or interests of the property in question. Therefore, it is possible to examine the division into two as dividing the physical structure of the goods and dividing the interests obtained from this item for reasons that terminate joint ownership. On the other hand, the joint good must be divisible in order to be divided and it must be the property of the shareholders during the distribution process. Likewise, it is not possible to revoke this from the binding procedure for the parties, which is done properly and fairly.

Although there is not much work in the literature regarding the distribution of common property in Islamic-Ottoman property law, there are some interesting studies. In these studies, the subject has been handled and analyzed in the framework of Islamic law from a theoretical perspective. What makes this study different from the previous ones is that it includes the Ottoman practice as well as examining the subject within the framework of the provisions of Islamic law. For this reason, in our study, some examples from the Ottoman practice are given after considering the issue of the division of the common property in a holistic manner and examining the Islamic law theory.
\end{abstract}

Key words: Joint Property, Joint Ownership, Owner, Distribution, Share. 


\section{GİRiş}

İnsanın diğer insanlarla olan ilişkileri hukukun konusu olduğu gibi, insanın eşya ile olan ilişkisi de hukukun konusunu oluşturmaktadır. Zira insanın eşya ile arasında kurmuş olduğu bağ, doğrudan ya da dolaylı olarak başkalarını da ilgilendirebilmektedir. Dolayısılla bireysel, sosyal ve ekonomik hayatın devamlılığı, düzeni ve gelişimi açısından insan ile eşya arasındaki bağın hukuki temellere oturtulması zorunluluk arz etmektedir. Doğası gereği eşyaları sahiplenme ve mülk edinme arzusu insanın fitratında olduğundan insan hayatı için zaruri olan eşyaların paylaşımı, mülk edinilmesi, üzerinde tasarruf edilmesi ve nihayetinde bu tasarrufun mahiyeti tarih boyunca tartışma konusu olmuştur. Bu kapsamda tarih boyunca her toplumda eşya ve mülkiyete ilişkin hukuki esaslar benimsendiği gibi İslam hukuku da bu konuyla ilgili olarak orijinal esaslar benimsemiștirir. Keza Osmanlı Devleti de hukukun diğer alanlarında olduğu gibi eşya hukuku sahasında da esasen İslam hukukunu tatbik etmiş olduğundan İslam hukukundaki mülkiyet anlayışı, Osmanlı hukukunda da hemen hemen aynı şekilde kabul edilip uygulanmıştır'.

Sözlük anlamı olarak "bir şeye hâkim olma ve onu ele geçirme" anlamlarına gelen mülkiyet hakkı, hukuki bir engel bulunmadığı sürece sahibine eşya üzerinde tasarruf yetkisi verdiği halde aynı eşya üzerinde başkalarının tasarrufunu engelleyen bir hâkimiyet hakkıdır ${ }^{3}$. İslam hukukçularına göre maddi bir varlığa sahip olan eşyalar mülkiyet hakkının konusunu teşkil edebileceği gibi maddi bir varlığa sahip olmamakla birlikte maddi varlığa sahip eşyalardan yararlanma anlamına gelen menfaatler de mülkiyetin konusunu oluşturabilirler. Günümüz eşya hukukunda olduğu gibi

Yaka, Zeki (2014) "İslam Hukukunda Zilyedlik ve Mülkiyet Arasındaki Farklar”, Bülent Ecevit Üniversitesi İlahiyat Fakültesi Dergisi, C: 1, S: 2, s. 36; Özdemir, Recep (2019) "İslam Hukukuna Göre Mülkiyet ve Mülkiyetin Temellendirilmesi”, Adıyaman Üniversitesi Sosyal Bilimler Enstitüsü Dergisi, Y: 11, S: 31, s. 260.

2 Cin, Halil (1992) Osmanlı Toprak Düzeni ve Bu Düzenin Bozulması, 3. Baskı, Konya, Selçuk Üniversitesi Basımevi, s. 9.

3 Türk Hukuk Kurumu (1991) Türk Hukuk Lûgatı, 3. Baskı, Ankara, Başbakanlık Basımevi, s. 255 . 
İslam-Osmanlı hukukunda da prensip itibariyle mütemmim cüzler, teferruat ve her çeşit semere mülkiyetin kapsamına dâhildir ${ }^{4}$. Bununla birlikte İslam hukukçuları mütemmim cüz ve teferruat tabirlerini kullanmak yerine "zevâid" ibaresini kullanmayı tercih etmişlerdir".

Öte yandan eşya üzerindeki mutlak hakların en güçlüsü olan mülkiyet hakkı, günümüz hukuk literatüründe daha çok Roma hukuku temeline dayanan ve bazı Batı dillerinde "property" ya da "propriété" kelimeleriyle ifade edilen terimin karşıllğı olup, mülkiyetin bu anlamda İslam hukukunda tek kelimelik bir karşılığı bulunmamaktadır. Fıkıh terminolojisinde ayni hakları ifade etmek üzere kullanılan "milk" kavramı ise günümüz hukukundaki mülkiyet hakkını da kapsayan bir üst kavram olup, bu anlamda mülkiyetin İslam hukukundaki tam karşılığı ise “milkü’l ayn ve’l-menfaa, elmilkü’l-kâmil, el-milkü’l-mutlak, el-milkü't-tâm” terimleriyle ifade edilmektedir. Bununla birlikte mülkiyet hakkı milkin en önemli örneği olduğundan, bir üst kavramın mutlak kullanılmasının da onun en mükemmel türüne yorumlanacağı kaidesinden hareketle yalnızca milk ya da milkü'l-ayn tabirleri ile de mülkiyet hakkı ifade edilebilir 6 .

Diğer taraftan İslam hukuku mülkiyetin kazanılması ve kullanılmasıyla ilgili olarak ahlaki açıdan önemli yenilikler getirmiş olmakla birlikte özel mülkiyetin temeline de dokunmamıştır?. Nitekim Kur'an-1 Kerim'de yer alan çeşitli ayetler ve Hz. Peygamber'in bazı söz ve uygulamaları İslam hukukunda

4 "Vücutta bir şeye tâbi olan, hükümde dahi ana tâbi olur.", "Tâbi olan şeye ayrica hüküm verilemez.", "Bir şeye malik olan kimse anın zaruriyetinden olan şeye dahi malik olur.", Mecelle-i Ahkâm-1 Adliyye (MAA), m. 47-49.

5 Cin, Halil/Akgündüz, Ahmed (2011) Türk Hukuk Tarihi, İstanbul, Osmanlı Araştırmaları Vakfi, s. 673; Ali Haydar Efendi (2014) Dürerü'l-Hukkâm Şerhu Mecelleti'l-Ahkâm, C. I, (Çeviren: Gündoğdu, Raşit/Erdem, Osman) İstanbul, Gül Neşriyat, s. 142; Aydın, Mehmet Akif (2014) Türk Hukuk Tarihi, 12. Baskı, İstanbul, Beta Basım Yayım, s. 337; Türkmen, Ali (1996) İslam Eşya Hukuku, Samsun, s. 28.

6 Hacak, Hasan (2005a) "İslam Hukuk Düşüncesinde Özel Mülkiyet Anlayışı", Marmara Üniversitesi İlahiyat Fakültesi Dergisi, C: 29, S: 2, s. 100-101; Hacak, Hasan (2006a) “Mülkiyet", Türkiye Diyanet Vakfı İslam Ansiklopedisi, C: 31, s. 543.

7 Armağan, Servet (2015) İslam Hukukunda Temel Hak ve Hürriyetler, 8. Baskı, Ankara, Diyanet İşleri Başkanlığı Yayınları, s. 174-178. 
özel mülkiyetin meşruluğunun dayanağı olarak gösterilebilir. Bu kapsamda Kur'an'da mülkiyet ile ilgili olarak yer alan ayetler incelendiğinde bu ayetlerin bir bütünlük teşkil edecek şekilde birbirine bağlı ve bütünlük içerisinde mülkiyetin Allah'a $^{8}$, topluma ${ }^{9}$ ve özel kişilere ${ }^{10}$ ait olabileceğini belirten nitelikte olduğu görülmektedir. Zira her şeyi yoktan var eden Allah, aynı zamanda yarattığı her şeyin gerçek anlamda sahibidir. Bununla birlikte İslam inancına göre imtihan için bu dünyada bulunan insan, bu imtihanın bir parçası olarak Allah tarafından yaratılmış olan şeylerin bir kısmına sahip ve malik olabilecektir. Öte yandan İslam hukukunun asli kaynaklarından ikincisi olan Hz. Peygamber'in sünnetinde ise doğrudan özel mülkiyete ilişkin bir hadis bulunmamakla birlikte, zekâta ve mirasa ilişkin hadislerden yola çıarak özel mülkiyetin Hz. Peygamber'in sünneti ile de desteklendiğini

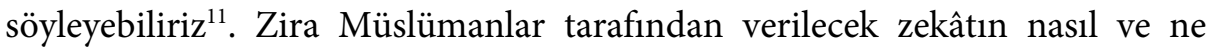
oranda olacağı ile ilgili hükümlerin yer aldığı bu hadislerden zekâtla yükümlü olmanın şartının da öncelikle bir mala malik olmak olduğu anlaşılmaktadır. Keza miras paylarından söz edilen bir diğer hadiste ise ölen kişinin geride bıraktığı malvarlığının mirasçıları arasında Kur’an-ı Kerim'de belirtilen oranlara uygun olarak paylaştırılmasından söz edilmekle birlikte kişinin ölümünden sonra geride mirasçılarına intikal edecek bir malvarlığının bulunması için öncelikle sağlı̆̆ında o malvarlığına malik olması gerekmektedir. Bununla birlikte önemle belirtmek gerekir ki Hz. Peygamber,

8 “(Onlara) 'Göklerde ve yerde olanlar kimindir?' diye sor. 'Allah'indır.' de.”, En'am, 4/12; "Musa kavmine dedi ki: Allah'tan yardım isteyin ve sabredin. Şüphesiz ki yeryüzü Allah'ındır. Kullarından dilediğini ona varis kılar.”, Araf, 7/128, Karaman, Hayrettin/Özek, Ali/Dönmez, İbrahim Kâfi/Çağrıcı, Mustafa/Gümüş, Sadrettin/Turgut, Ali (2014), Kur’an-ı Kerim ve Açıklamalı Meâli, 27. Baskı, Ankara, Türkiye Diyanet Vakfı Yayınları.

9 "Hor görülüp ezilmekte olan o kavmi (Yahudileri) de, içini bereketle doldurduğumuz yerin doğu taraflarına ve batı taraflarına mirasçı kıldık.", Araf, 7/137; "Andolsun Zikir'den sonra Zebur'da da: 'Yeryüzüne iyi kullarım varis olacaktır.” diye yazmıştık.” Enbiya, 21/105.

"Yetimin malına, rüştüne erinceye kadar, ancak en güzel bir niyetle yaklaşın. Verdiğiniz sözü de yerine getirin. Çünkü verilen söz, sorumluluğu gerektirir.", İsra, 17/34; "Ey iman edenler! Allah'a ve ahiret gününe inanmadiğı halde malını gösteriş için harcayan kimse gibi, başa kakmak ve incitmek suretiyle, yaptığııız hayırlarınızı boşa çıkarmayın.”, Bakara, 2/264.

11 Müslim, "Zekât”, 1,7; Müslim, "Feraiz", 2. 
sahibinin izni olmadan başkasına ait mala el uzatılmaması gerektiği ilkesini sık sık vurguladığı gibi meşru müdafaa şartları içerisinde malını korumaya çalışırken öldürülen kişinin de şehit mertebesinde sayılacağını haber vermiştir ${ }^{12}$.

İslam-Osmanlı hukukunda mülkiyet hakkı çeşitli açılardan farklı sınıflandırmalara tabi tutulabilir. Bu kapsamda konusu bakımından mülkiyet hakkı ayn, deyn, ve menfaat mülkiyeti olmak üzere üçe ayrılır. Rakabe mülkiyeti adı da verilen ayn mülkiyeti, bir şeyin bizzat kendisine, dolayısıyla o şeyin kullanma ve yararlanma hakkına da sahip olmak anlamına gelmektedir $^{13}$. İslam hukuku literatüründe esasen ayn mülkiyeti başkasına ait olan bir malın yalnızca yararlanma hakkına sahip olmaya menfaat mülkiyeti adı verilmekte olup, mülkiyetin bu türü kira, ariyet, vakıf ve vasiyet gibi hukuki işlemlerden biriyle kurulabilirr ${ }^{14}$. Deyn mülkiyeti ise İslam hukukunda kişinin başkalarından olan alacak haklarına verilen isimdir. Öte yandan sahibine bağışladığı yetkiler bakımından mülkiyet hakkı kâmil (tam) ve nâkıs (eksik) mülkiyet olmak üzere ikiye ayrılmaktadır. Bu kapsamda bir malın ayn mülkiyeti ile birlikte menfaat mülkiyetine de sahip olmaya tam mülkiyet adı verilirken, malın yalnızca ayn mülkiyetine ya da yalnızca menfaat mülkiyetine sahip olunmasına ise eksik mülkiyet adı verilmektedir. Son olarak İslamOsmanlı hukukunda hak sahiplerinin sayısına göre mülkiyet hakkı müstakil mülkiyet ve müşterek mülkiyet olmak üzere ikiye ayrılmaktadır. Bir malın mülkiyetine bir kişinin tek başına sahip olması halinde müstakil mülkiyet söz konusu olduğu halde malın mülkiyetinin birden fazla kişiye ait olması halinde ise müşterek mülkiyet söz konusu olur ${ }^{15}$.

12 Buhari, “İlim”, 9, 37; Müslim, “İman”, 226.

13 Çalış, Halit (2007) “Rakabe”, Türkiye Diyanet Vakfı İslam Ansiklopedisi, C: 34, s. 427-428; Fendoğlu, Hasan Tahsin (1994) Hukuk Tarihimizde Temel Haklar, Konya, Mimoza, s. 144-145.

14 Hacak, Hasan (2004) “Menfaat”, Türkiye Diyanet Vakfi İslam Ansiklopedisi, C: 29, s. 131134.

15 Ekinci, Ekrem Buğra (2017) Osmanlı Hukuku: Adalet ve Mülk, 5. Basım, İstanbul, Arı Sanat Yayınevi, s. 475-478; Ekinci, Ekrem Buğra (2016) İslam Hukuku: Umumi ve Hususi Hükümler, 2. Basım, İstanbul, Arı Sanat Yayınevi, s. 443-445; Avcı, Mustafa (2018) Türk 
İslam-Osmanlı eşya hukukunda müşterek malın paylaştırılması hususunda öğretide fazlaca bir çalışma olamamakla birlikte ilgi çekici bir kısım çalışma bulunmaktadır. Bu bağlamda "İslam Fıkıh Doktrininde Müşterek Mülkiyetin Taksiminde Muhdesatın Durumu (İştirak ve Müşterek Araziler Örneği)" ${ }^{\prime 16}$ isimli makalede müşterek malın taksimi hususu İslam hukuku teorisi açısından ele alınıp incelendikten sonra paylaşımı yapılacak müşterek mal üzerindeki mütemmim cüz, teferruat ve semerelerin durumu irdelenmektedir. Öte yandan "İslam Hukukunda Müşterek Mülkiyet”"17 isimli yüksek lisans tezinde İslam hukukunda müşterek mülkiyeti meydana getiren sebepler, paydaşların müşterek maldaki tasarrufları ve müşterek mülkiyeti sona erdiren sebepler teorik açıdan bir bütün olarak ele alınıp incelenmektedir. Yine "İslam Hukukunda Muhâye'e"18 adlı yüksek lisans tezinde müşterek mülkiyet ve müşterek mülkiyetin taksimi hakkında genel bilgiler verildikten sonra müşterek maliklerin zaman sıralaması ya da parça belirlemek suretiyle müşterek maldan yararlanma usulü hakkında anlaşmaları anlamına gelen muhâye'e hakkında İslam hukuku teorisi ele alınıp incelenmektedir. "İslam-Osmanlı Eşya Hukukunda Müşterek Mülkiyetin Taksimi” ismini verdiğimiz bu çalışmayı öncekilerden ayıran husus ise konuyu yalnızca İslam hukuku çerçevesinde teorik olarak ele alıp incelemek yerine Osmanlı Devleti uygulamasının da tebarüz ettirilmeye çalışılmasıdır.

$\mathrm{Bu}$ kapsamda çalışmamızda öncelikle İslam-Osmanlı hukukunda müşterek mülkiyetin tanımını yaparak kuruluşu ve sona ermesi hakkında bilgi vereceğiz. Sonrasında ise müşterek mülkiyeti sona erdiren sebeplerden taksim hususunu ele alıp inceleyeceğiz. Çalışmamız esnasında müşterek mülkiyet ve

Hukuk Tarihi, 7. Bası, Konya, Atlas Akademi, s. 509-513; Aydın (2014), s. 337-341; Cin/Akgündüz, s. 674-677; Hacak (2006a), s. 545-546; Fendoğlu, s. 44.

16 Sağlam, Hadi (2012) "İslam Fıkıh Doktrininde Müşterek Mülkiyetin Taksiminde Muhdesatın Durumu (İştirak ve Müşterek Araziler Örneği)”, Cumhuriyet Üniversitesi İlahiyat Fakültesi Dergisi, C: 16, S: 2, s. 365-415.

17 Çelen, Cevdet (2010) “İslam Hukukunda Müşterek Mülkiyet” (Yüksek Lisans), Marmara Üniversitesi, Sosyal Bilimler Enstitüsü.

18 Kâhya, Özlem (2009) "İslam Hukukunda Muhâye'e” (Yüksek Lisans), Marmara Üniversitesi, Sosyal Bilimler Enstitüsü. 
müşterek mülkiyetin taksimi hususunda bir taraftan İslam hukuku teorisini incelerken, diğer taraftan ise Osmanlı uygulamasından örnekler vereceğiz.

\section{I. İSLAM-OSMANLI HUKUKUNDA MÜSTTEREK MÜLKIYYET}

$\mathrm{Bu}$ başlık altında müşterek mülkiyetin tanımı yapılarak müşterek mülkiyeti meydana getiren sebepler, müşterek maliklerin mal üzerindeki tasarrufları ve müşterek mülkiyeti sona erdiren nedenler üzerinde durulacaktır.

\section{A. GENEL OLARAK}

İslam hukuku literatüründe "şirket-i milk" kavramıla ifade edilen müşterek mülkiyet; satın alma, hibe, vasiyeti kabul veya miras gibi mülkiyeti kazanma yollarından biriyle ya da birden fazla malın ayrılması mümkün olmayacak bir biçimde birbirlerine karışarak birleşmesi suretiyle en az iki kimsenin bir mal üzerinde birlikte malik olmalarıdır. Mülkiyetin bu çeşidinde belirli mal üzerinde 1/3,1/4,1/5 gibi belirli oranda bir hisseye sahip olan şahıs, o malın tamamında payı oranında mülkiyet hakkına sahip olur. Bu sebeple malın müşterek maliklerinden herhangi birisi mal üzerinden kendi hissesi kadar bir yer veya parçayı belirleyerek yalnızca ona malik olamaz. Müşterek mülkiyete konu teşkil eden mal üzerinde pay sahiplerinin belirli orandaki paylarına müşầ, söz konusu malda bulunan ve malın tamamını kapsayan paya ise hisse-i şâyi'a adı verilmektedir ${ }^{19}$.

İslam hukukçuları müşterek mülkiyeti çeşitli açılardan farklı sınıflandırmalara tabi tutmuşlardır. Bu kapsamda müşterek mülkiyetin oluşumunda pay sahiplerinin irade ya da fillerinin olup olmamasına göre

19 MAA, m. 138-139; m. 1060; Ali Haydar, C. I, s. 145; Cin/Akgündüz, s. 676; Ekinci (2017), s. 477; Ekinci (2016), s. 444; Aydın (2014), s. 341; Çelen, s. 59; Bilmen, Ömer Nasuhi (t.y.) Hukuk-1 İslamiyye ve Istılahat-1 Fikhiyye Kâmusu, C. VII, İstanbul, s. 65; Karaman, Hayrettin (2012) Mukayeseli İslam Hukuku, C. III, İstanbul, İz Yayıncılık s. 51; Kahveci, Nuri (2015) Mukayeseli İslam Borçlar Hukuku, 1. Baskı, İstanbul, Hikmet Yayınevi, s. 278; Hacak, Hasan (2006b) “ Müşầ ”, Türkiye Diyanet Vakfi İslam Ansiklopedisi, C: 32, s. 151152. 
müşterek mülkiyet, şirket-i ihtiyâriye ve şirket-i cebriye olmak üzere ikiye ayrılmaktadır. Günümüz eşya hukukundaki müşterek mülkiyet kavramının İslam-Osmanlı hukukundaki tam karşıllı̆̆ olan şirket-i ihtiyâriye, pay sahiplerinin kendi fiil ya da iradeleri sonucu meydana gelen ortaklık türüdür. Pozitif hukukumuzda elbirliği mülkiyeti şeklinde ifade edilen şirket-i cebriye ise pay sahiplerinin kendi fiil ya da iradeleri sonucu değil de başka bir sebebe bağlı olarak ortaya çıkan ortaklık şeklidir. Şirket-i cebriye birden fazla malın ayrılması mümkün olmayan bir şekilde birbirine karışması veya bir malvarlığının miras yoluyla birden fazla mirasçıya intikal etmesi şeklinde ortaya çıkabilir ${ }^{20}$.

Müşterek mülkiyete konu olan malın eşya veya alacak hakkı olması bakımından müşterek mülkiyet, şirket-i ayn ve şirket-i deyn olmak üzere ikiye ayrılmaktadır. Şirket-i ayn, iki veya daha fazla kişinin belirli ve fiziki bir varlığa sahip olan eşya üzerinde ortak malik olmalarıdır. Şirket-i deyn ise iki veya daha fazla kişinin bir başkasının zimmetinde bulunan alacağa ortak olmalarına verilen isimdir ${ }^{21}$.

$\mathrm{Bu}$ çerçevede İslam hukukunda müşterek mülkiyetin tanımı ve özelliklerinin pozitif hukukumuzla benzerlik gösterdiği söylenebilir. Öte yandan çalışmamızın bir sonraki başlığı altında İslam-Osmanlı eşya hukukunda müşterek mülkiyeti oluşturan sebepler hakkında bilgi vermekte yarar vardir.

\section{B. MÜŞTEREK MÜLKIYYETIN KURULUŞU}

İslam-Osmanlı eşya hukukunda müşterek mülkiyet; satım sözleşmesi, bağışlama, miras, vasiyet, sadaka, ganimet ve iki ya da daha fazla malın ayrılması mümkün olmayan şekilde karışması veya birleşmesi gibi yollardan biriyle meydana gelmektedir. Günümüz hukukunda mülkiyeti nakledici

20 MAA, m. 1045, 1060-1064; Ali Haydar Efendi (2014) Dürerü'l-Hukkâm Şerhu Mecelleti'lAhkâm, C. III, (Çeviren: Gündoğdu, Raşit/Erdem, Osman) İstanbul, Gül Neşriyat, s. 141144; Cin/Akgündüz, s. 676; Aydın (2014), s. 341; Avcı, s. 513; Kahveci, s. 278.

${ }^{21}$ MAA, m. 1066-1068; Ali Haydar, C. III, s. 145-146; Kahveci, s. 278; Çelen, s. 60; Kâhya, s. 18. 
sözleşmelerden olan satım sözleşmesi İslam-Osmanlı hukuk literatüründe “ bey' " kavramı ile ifade edilmiştir. Sözlük anlamı olarak "mübadele” anlamına gelen bey', bir hukuk terimi olarak da sözlük anlamı ile bağlantılı olarak "malı mal ile değiştirmek” anlamına gelmektedir. Satım sözleşmesinde alıcı, tek kişi olabileceği gibi birden fazla kişinin aynı malı ortaklaşa satın almaları da mümkündür. Böylece iki veya daha fazla kişinin ortaklaşa aldıkları mal üzerinde malı satın alan alıcılar arasında müşterek mülkiyet meydana gelmektedir ${ }^{22}$.

Müşterek mülkiyetin kurulması yollarından biri olan bağışlama ise İslam-Osmanlı hukuk literatüründe "hibe" olarak isimlendirilmiş olup, bu kapsamda kişinin maliki olduğu bir malvarlığını henüz hayatta iken karşılıksız olarak bir başkasına temlik etmesine hibe adı verilmiştir. Bağışlamanın kurucu unsurları icap ve kabul olmakla birlikte kendisine bağış yapılan taraf, bağışlanan şeyi teslim almadıkça bağışlama işlemi gerçekleşmiş sayılmaz. Keza bağışlamada kendisine bağış yapılan taraf bir kişiden oluşabileceği gibi birden fazla kişinin de birlikte bağışı kabul etmeleri mümkündür. Böylelikle kendilerine yapılan bağışı kabul ederek bağışlanan malı teslim alan kişilerin söz konusu malı teslim aldıkları anda müşterek mülkiyet ortaya çıkmış olur ${ }^{23}$.

Öte yandan müşterek mülkiyeti meydana getiren sebeplerden biri olan miras sözlük anlamı olarak "bir şeyin bir kişi veya topluluktan diğerine geçmesi, başkasından kalan, tevarüs edilen şey” gibi anlamlara gelmekte olup, hukuk terimi olarak ise ölen bir kişinin (muris) geride bıraktığı malvarlığının akıbetini düzenleyen kurallar topluluğudur ${ }^{24}$. Murisin geride biraktığ 1

22 MAA, m. 105; Ali Haydar, C. I, s. 134-135; Bardakoğlu, Ali (1992) “ Bey” ”, Türkiye Diyanet Vakfi İslam Ansiklopedisi, C: 6, s. 13-14; Bilmen, Ömer Nasuhi (t.y.) Hukuk-1 İslamiyye ve Istılahat-1 Fıkhiyye Kâmusu, C. VI, İstanbul, s. 14; Cin/Akgündüz, s. 645-646; Kahveci, s. 186-187; Çelen, s. 60-61.

23 MAA, m. 833, 837-838; Ali Haydar Efendi (2014) Dürerü'l-Hukkâm Şerhu Mecelleti'lAhkâm, C. II, (Çeviren: Gündoğdu, Raşit/Erdem, Osman) İstanbul, Gül Neşriyat, s. 374386; Bardakoğlu, Ali (1998) "Hibe", Türkiye Diyanet Vakfı İslam Ansiklopedisi, C: 17, s. 421-423; Bilmen, Ömer Nasuhi (t.y.) Hukuk-1 İslamiyye ve Istılahat-1 Fikhiyye Kâmusu, C. IV, İstanbul, s. 501; Cin/Akgündüz, s. 651; Ekinci (2017), s. 523; Ekinci (2016), s. 522-523.

24 Aktan, Hamza (2005) "Miras", Türkiye Diyanet Vakfı İslam Ansiklopedisi, C: 30, s. 143; Cin/Akgündüz, s. 541; Avcı, s. 465. 
malvarlığına tereke adı verilmekte olup terekenin kapsamına dâhil olan ve olmayan mal ve haklarla ilgili olarak İslam hukukçuları arasında görüş ayrılığı mevcuttur. Şafii ve Hanbeli mezheplerine mensup hukukçulara göre murisin geride bıraktığı mal ve hakların tamamı terekeye dâhil olduğu halde Malikiler hakların terekeye dâhil olması için bölünebilir olması şartını ararlar. Buna karşın Hanefi mezhebine mensup hukukçulara göre ise kira, ariyet gibi hukuki işlemlerden doğan menfaatler; velâyet, vekâlet, hidâne ${ }^{25}$ gibi şahsa sıkı sıkıya bağlı haklar; şüf $a^{26}$ hakkı ile şart muhayyerliği, görme muhayyerliği gibi doğrudan hukuki işlemin tarafı olan şahsın kişisel tercihleriyle ilgili muhayyerlikler terekeye dâhil değildir. Ancak ayıp muhayyerliği ve vasıf muhayyerliği gibi kişisel tercihlerle ilgili olmayıp doğrudan mal ile ilgili olan muhayyerlikler ise terekeye dâhil olup mirasçlara intikal eder. Öte yandan irtifak hakları şahıstan ziyade mala bağlı bir hak olduğundan, ölenin lehinde tahakkuk eden diyet ve diğer alacak hakları da zimmete sabit olan bir hak olarak kabul edildiği için tereke kapsamına dâhil sayılır ${ }^{27}$. Bu bağlamda Osmanlı uygulamasında Osmanlı Devleti'nin resmi mezhebi olan Hanefi mezhebine ait görüşlerin uygulamaya da yansıdı̆̆ını söyleyebiliriz ${ }^{28}$.

25 Küçük çocukların yetkili bir kimse tarafından belirli bir süre için gözetim ve terbiye edilmesi anlamına gelen "hidâne" hakkında ayrıntılı bilgi için bakınız: Bardakoğlu, Ali (1998) "Hidâne", Türkiye Diyanet Vakfı İslam Ansiklopedisi, C: 17, s. 467-471; Kıylık, Mustafa Harun (2016) "Aile İçi Eğitim Açısından İslam Hukukunda Hidane", Yurt, Mehmet Emin/Bayrktutan Osman (Editörler), Iğdır Üniversitesi İlahiyat Fakültesi Uluslararası Aile İçi Eğitim Çalıştayı, Iğdır, s. 143-178.

26 Satım sözleşmesi veya benzeri bir akitle alınmış taşınmaz veya taşınmaz mahiyetindeki özel mülkiyete konu bir malı alıcıya mal olduğu bedelle cebren alıp mülkiyetini elde etme hakkı olan "şüfa" hakkında ayrıntılı bilgi için bakınız: Dönmez, İbrahim Kâfi (2010) "Şüfa", Türkiye Diyanet Vakfı İslam Ansiklopedisi, C: 39, s. 248-252; Yıldırım, İlyas (2018) "ŞüfaÖnalım Hakkı: Mecelle ve Türk Medeni Kanunun Merkezli Bir Mukayese”, İslam Hukuku Araştırmaları Dergisi, S: 31, s. 317-336.

27 Aydın (2014), s. 300; Cin/Akgündüz, s. 552; Cin, Halil/Akyılmaz, Gül (2013) Türk Hukuk Tarihi, 5. Baskı, Konya, Sayram Yayınları, s. 463; Aktan (2005), s. 144; Avcı, s. 466; Bilmen, Ömer Nasuhi (t.y.) Hukuk-1 İslamiyye ve Istılahat-1 Fıkhiyye Kâmusu, C. V, İstanbul, s. 209 vd.

28 "Medîne-i Hazret-i Ebî Eyyûb el-Ensârî̀ -dâme fî rıdvâni'l-Bârî-'de Otakçıbaşı mahallesi sâkinlerinden olup bundan akdem fevt olan İbrahim b. Turgud nâm müteveffânın verâseti sulbiye kebîre kızları Fâtıma ve Torbayişe ve Bâşe nâm hâtunlara münhasıra olup ba'dehû 
Müşterek mülkiyeti meydana getiren sebeplerden birisi olan vasiyet sözlük anlamı olarak; "bir işin yapılmasını bir kimseye ısmarlamak, sipariş vermek, bağlamak, bitiştirmek” gibi anlamlara gelmektedir. Vasiyet bir hukuk terimi olarak ise kişinin sahibi olduğu belli bir mal ya da menfaati ölümünden sonra geçerli olmak üzere bir şahsa veya hayır cihetine karşılıksız olarak bağışlamasını ifade etmektedir. Bu çerçevede hukuki açıdan gerekli şartları bünyesinde bulundurmak kaydıyla lehine mal veya menfaat vasiyet edilen tarafın birden fazla kişiden oluşması mümkündür. Dolayısıyla geçerli bir vasiyet ile birden fazla kişi lehine vasiyette bulunulması ve böylelikle vasiyete

kable'l-kısme merkūme Bâşe Hâtun dahi müteveffât olup verâseti sadrî kebîr oğlu İshak Halîfe b. () ile sadrî kebîre kızı Âşir nâm hâtuna münhasıra olduğu şer'an zâhir ve müte'ayyin oldukdan sonra merkūm İshak Halîfe hus ûs-ı âti'z-zikri da'vâya kendi tarafindan asâleten ve karındaşı mersûme Âşir Hâtun tarafindan vekîli olup nehc-i şer'iyy-i mu'teber üzre şer'an vekâleti sâbite olmağla vekâleten meclis-i şer'-i şerîf-i lâzımü't-teşrîfde işbu râfi ü̈l-kitâb İsâ b. Budak nâm kimesne husûs-ı câ'i'z-zikre kendi kıbelinden asîl ve zevcesi mezbûre Fâtıma Hâtun cânibinden vekîl-i şer'îsi olmağla muvâcehesinde bi'l-asâle ve bi'lvekâle üzerine takrîr-i da'vâ edip müteveffâ-yı evvelin muhallefâtından olup mahalle-i mezbûrede vâki' lede'l-cîrân ma'lûmetü'lhudûd olan menzil irs-i şer'le mezbûretân Fâtıma ve Torbayişe'ye ve vâlide ve müteveffâ-yı mersûmeye intikāl etmişiken mezbûre Fâtıma Hâtun ve zevci merkūm İsâ otuz sene mikdârı cümle menzili zabt ve tasarruf etmişlerdir, hâlen vâlidemiz vefât etmekle menzil-i mezbûrdan üç sehimden bir sehim hisse bana ve klz karındaşım merkūme Âşir Hâtun'a intikāl etmeğin hisse-i mersûmenin icâre-i mislini asâlet ve vekâlet ve verâset-i mahkiyem hasebiyle merkūmân Fâtıma Hâtun ve zevci İsâ'dan taleb ederin mezbûr İsa'dan suâl olunup () dedikde gıbbe's-suâl mezbûr İsâ cevâbında fi'l-vâki' menzil-i merkūmda bu kadar zamân müteveffât-ı mezbûre muvâcehesinde sâkini olduğumuz mukarrer lâkin müteveffât-ı mezbûre hâl-i hayâtında ücret-i şerî̀ olmamağla bizden bir şey da'vâ etmemişdir deŷ̂ hâlen şeyhülislâm ve müfti'l-enâm sellemehü's-selâm hazretlerinden yedinde olan fetvâyı şerîfesini ibrâz ve mezbûr İshak Halîfe mahzarında kırâ'at olundukda mazmûn-ı şerîfinde Zeyd fevt olup kebîre kızları Hind ve Zeyneb ve Âişe'yi terk e[t]dikde tereke[-i] Zeyd'den olan bir mülk menzilde Hind zevci Amr ile birkaç sene sâkin olup hâlen

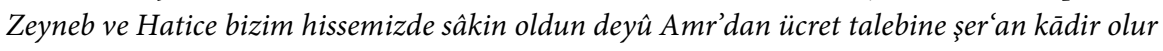
mu deyû istiftâ olundukda cevâb-ı bâ-savâblarında olmazlar deyû buyrulmağın ber mûceb-i fetvâ-yı şerîf mezbûr İshak Halîfe bî̀-vech mu['â]razadan me[n]' olunup mâ hüve'l-vâki' bi'libtigā ketb olundu." Yılmaz, Coşkun (editör) (2011) İstanbul Kadı Sicilleri Eyüb Mahkemesi (Havâss-1 Refîa) 61 Numaralı Sicil (H. 1065-1066 / M. 1655), C: 27, İstanbul, İSAM, s. 256-257, Hüküm No: 287 [58b-1]. 
konu olan malın vasiyetten yararlanacak olan kişilere intikali ile müşterek mülkiyet kurulmuş olur ${ }^{29}$.

Keza gönüllü olarak ya da dini bir vecibeyi yerine getirmek üzere ihtiyaç sahiplerine yapılan maddi yardım anlamına gelen sadaka da bazı İslam hukukçuları tarafından müşterek mülkiyeti oluşturan sebeplerden biri olarak kabul edilmektedir ${ }^{30}$.

Diğer taraftan sözlük anlamı olarak "bir şeyi zorluk çekmeden elde etmek" anlamına gelen ganîmet, İslam hukuku literatüründe "Müslümanların savaş yoluyla gayrimüslimlerden ele geçirdikleri her türlü mal ve esirler" şeklinde tanımlanmıştır. Bununla birlikte bazı İslam hukukçuları ganimeti yalnızca savaşan düşman askerlerinden ele geçirilen menkul mallardır şeklinde tanımlamışlardır. İslam hukukçularının çoğunluğuna göre ganimet üzerinde ele geçirildiği andan itibaren mülkiyet hakkı sabit olduğu halde Hanefi mezhebine mensup hukukçulara göre ise mülkiyet hakkının sabit olması için öncelikle dârülislam (İslam ülkesi) topraklarına ulaşmak gerekir. Ancak önemle belirtmek gerekir ki İslam hukukçularının görüş ayrılığında olduğu husus ganimet üzerinde mülkiyetin nerede ve ne zaman tesis edileceğine ilişkin olup, her halükârda mülkiyetin oluşacağı hususunda İslam hukukçuları ittifak etmişlerdir. Dolayısıyla ganimet üzerinde mülkiyetin sabit olmasıyla birlikte meydana gelen mülkiyet türü müşterek mülkiyet olup, savaşa katılan gazilerin tamamının ele geçirilen mallar üzerinde payları söz konusu olur. Bununla birlikte Hanefilere göre gazilerin mülkiyet haklarının sabit olabilmesi için zilyetliğin İslam ülkesinde de devam etmesi gerektiğinden, savaşa katıldığı dârülharpte iken ölen askerlerin ganimetten pay almaları mümkün olmadığı gibi bunların paylarının ayrılarak mirasçılarına intikal ettirilmesi de söz konusu değildir. Keza Hanefi mezhebine mensup hukukçulara göre ganimet malları taksim edilirken

29 MAA, m. 1063; Ali Haydar, C. III, s. 144; Cin/Akgündüz, s. 542-544; Aydın (2014), s. 305 306; Avcı, s. 481-482; Cin/Akyılmaz, s. 465; Arı, Abdüsselam (2012) "Vasiyet", Türkiye Diyanet Vakfi İslam Ansiklopedisi, C: 42, s. 552-554; Bilmen, C. V, s. 115 vd.

30 MAA, . 835; Ali Haydar, C. III, s. 377-378; Duman, Ali (2008) "Sadaka", Türkiye Diyanet Vakfı İslam Ansiklopedisi, C: 35, s. 383-384; Çelen, s. 63-64. 
piyadelere birer, süvarilere ise ikişer hisse verildiği gibi komutan da gazilerden biri olarak ganimetten pay alır ${ }^{31}$.

Birden fazla malın birbirinden ayrılması mümkün olmayacak veya ayrılması çok zor ve masraflı olacak şekilde birbirine karıştırılması durumunda ortada bir karıştırma veya birleşme ya da İslam-Osmanlı hukuk literatüründeki ismiyle halt ve ihtilât-1 emvâl var demektir. Bu durumda karıştırılan ya da birleşen malları birbirinden ayırmak mümkün olmadığından halt ve ihtilât-1 emvâl kaçınılmaz olarak mülkiyeti kazanma yollarından biri olmaktadır. Bununla birlikte karıştırma ve birleşme ile ortaya çıkan malın mülkiyetinin kime ait olacağı karışan veya birleşen malların değerine ya da müşterek mülkiyetin mümkün olup olmamasına göre değişiklik gösterebilmektedir. Birden fazla taşınmazın kimsenin müdahalesi olmaksızın bir araya gelmesi halinde değeri fazla olan taşınmazın maliki, değeri az olanın bedelini ödeyerek ortaya çıkan malın müstakil mülkiyetine sahip olur. Taşınırlarda ise iki farklı durum söz konusudur ki bunlardan ilkine göre birden fazla kişiye ait buğday veya mısır gibi cins malların birbirine karıştırılması halinde olduğu gibi müşterek mülkiyet imkânı varsa karışan malların malikleri meydana gelen mala kendi payları oranında müştereken sahip olurlar. Ancak bir tavuğun bir inciyi yutması durumu gibi ortaya çıkan karıştırma veya birleşme hallerinde ise değeri fazla olan malın sahibi, az olanın değerini ödeyerek ona da sahip olur ${ }^{32}$.

İslam eşya hukuku ve Osmanlı uygulamasında müşterek mülkiyetin oluşumuna ilişkin verdiğimiz bu bilgilerin ardından ortakların müşterek mal üzerindeki tasarruf haklarından da söz etmekte fayda vardır.

31 Erkal, Mehmet (1996) "Ganimet”, Türkiye Diyanet Vakfı İslam Ansiklopedisi, C: 13, s. 351-354; Bilmen, Ömer Nasuhi (t.y.) Hukuk-1 İslamiyye ve Istılahat-1 Fıkhiyye Kâmusu, C. III, İstanbul, s. 337, 397; Ekinci (2016), s. 270-271; Ekinci (2017), s. 292-293; Çelen, s. 6667.

32 MAA, m. 902, 1060-1061; Ali Haydar, C. II, s. 510-511, C. III, s. 141-143; Aydın (2014), s. 346; Cin/Akgündüz, s. 679; Ekinci (2016), s. 447-448; Ekinci (2017), s. 479-480. 


\section{MÜŞTEREK MALDA PAY SAHIPLLRINNIN TASARRUFLARI}

Müstakil mülkiyete konu olan bir eşyaya yalnızca bir kişi sahip olduğu halde müşterek mülkiyete konu teşkil eden bir eşyanın birden çok maliki bulunmaktadır. Bununla birlikte müşterek olarak bir mala sahip olan pay sahipleri o malın belli bir bölümü üzerinde hisseleri oranında malik olmayıp, pay sahiplerinin mülkiyet hakkı malın tamamı üzerinde kendi hisseleri oranındadır. Bu nedenle bir malın müstakil mülkiyetine sahip olan şahıs o mal üzerinde dilediği gibi tasarruf edebildiği halde, müştereken bir mala sahip olan ortakların o mal üzerinde tasarruf yetkileri bazı kısıtlamalara tabidir. Bu kapsamda müşterek mülkiyete konu olan bir malvarlığı üzerinde müşterek maliklerden her biri kendi paylarına ilişkin olarak bazı tasarrufları tek başlarına yapabildikleri halde bir kısım tasarrufları ise sınırlandırılmıştır. Nitekim müşterek malın tamamını ilgilendiren tasarruflar ise pay sahiplerinin ittifakıyla mümkündür ${ }^{33}$.

Müşterek malikler uzlaşmak suretiyle müşterek olarak sahibi oldukları malı birlikte satabilecekleri gibi ortaklardan her birisi sahibi olduğu hisseyi diğer ortakların muvafakatine ihtiyaç duymaksızın pay sahiplerinden birine veya bir başkasına satabilir ${ }^{34}$. Ancak önemle belirtmek gerekir ki müşterek

33 MAA, m. 1069; Ali Haydar, C. III, s. 147; Hacak (2006b), s. 151; Cin/Akgündüz, s. 676; Ekinci (2017), s. 477; Ekinci (2016), s. 444; Aydın (2014), s. 341; Kâhya, s. 19; Türkmen, s. 36.

34 "Vilâyet-i Anadolu'da Arabkir Sancă̆ı'na tâbi" Eğin nâm kasaba sükkânından olan Kumru v. Ahî nâm Ermeni meclis-i şer'i hatîr-i lâzımü’t-tevkīrde işbu bâ'isü’l-kitâb Hortik v. Umurcan nâm Ermeni mahzarında bi't-tav'i's-sâf ikrâr ve takrîr-i kelâm edüp silk-i mülkümde münselik olup kasaba-i mezbûrede vâki' bir tarafı Mehmed Bey mülkü ve bir tarafi Ramazan Çelebi mülkü ve bir tarafi Yusuf Bey mülkü ve bir tarafı tarîk-ı hâs ile mahdûd ve mümtâz olan mülk menzilimi babam hâlik-i mezbûrdan karındașım Ahî nâm Ermeni ile ale'l-iştirâki's-seviy müşterek olduğumuz mülk menzilden ve mülk bağdan nısf hissemi mezbûr Kumru'ya [Hortik'e] iki yüz aded riyâlî guruşa ve bir kaftan bin akçe kıymetli ve bir çuka ferâceye bey'-ı bâtt-ı sahîh-i şerî̀ ile bey' edüp kabz-ı semen-i ma'dûd, mezbûru mahâllinde kabz, taslît eyledim. Ol dahi vech-i mübeyyen üzre iştirâ ve teslîm[tesellüm] eyledi. Ba'de'l-yevm zikrolunan menzil ve bağlar mezbûr Hortik['in] mülk-i müşterâsıdır. Keyfe mâ yeşâ ve yahtâr mutasarrıf olsun dedikde mukırr-ı merkūmun ikrâr-ı meşrûhunu el-mukarru lehu'l-mezbûr Hortik bi'l-muvâcehe tasdîk ve bi'l-müşâfehe tahkīk edicek mâ hüve'l-vâki` bi't-taleb ketb olundu.”, Yılmaz, Coşkun (editör) (2019) İstanbul 
mülkiyetin konusu gayrimenkul ise diğer ortakların şufa hakkı vardır ${ }^{35}$. Keza müşterek mülkiyetin birden fazla malın karıştırılması ya da birleşmesi ile oluşması halinde ortaklardan biri kendi payını diğerlerine satabildiği halde diğer ortakların rızası olmaksızın üçüncü kişilere satması hukuken caiz değildir ${ }^{36}$.

Diğer taraftan müşterek mülkiyete konu teşkil eden bir malın maliklerinden birinin kendi hissesini bağış, rehin veya kiraya verip veremeyeceği ya da pay sahiplerinin kendi hisseleri üzerinde vakıf kurup kuramayacağı konularında İslam hukukçuları arasında görüş ayrılığı vardır. Özellikle Hanefiler ortaklardan birinin müşterek maldaki hissesini bağış, rehin veya kiraya verip veremeyeceği ya da kendi payı ile vakıf kurup kuramayacağ noktasında söz konusu hissenin müstakil bir biçimde teslimi mümkün olmadığından ve işlemin sonucu yalnız bu hisseyi değil malın tamamını ilgilendirdiğinden diğer mezheplerden farklı görüşler ortaya koymuşlardır. Buna karşın Maliki, Şafii ve Hanbeli mezhepleri ise genel olarak ortaklardan birinin kendi payını rehin veya kiraya vermesini, bağışlamasını ya da vakfetmesini hukuki açıdan caiz görmüşlerdir ${ }^{37}$.

$\mathrm{Bu}$ kapsamda Hanefiler pay sahiplerinden birinin müşterek maldaki hissesini bağış olarak vermesini malın paylaştırılması mümkün değilse zaruretten dolayı kabul ederler ${ }^{38}$. Ancak paylaştırılması mümkün olan müşterek malın öncelikle paylaşılıp sonra bağışlayana düşen hissenin

Kadı Sicilleri 52 Hasköy Mahkemesi 3 Numaralı Sicil (H. 1023-1081 / M. 1615-1670), İstanbul, İstanbul Büyükşsehir Belediyesi Kültür A.Ş Yayınları, s. 75, Hüküm No: 68 [29-2].

35 "Bir menzilin ikişer sehmi Zeyd ve Hind'in, iki sehmi Amr'in bir sehmi Bekir'in olub mezbûrlar bu vechile a'le'l-iștirâk malikler iken Amr, menzilden hissesini semen-i ma'lûme Beşir'e bey' ve teslim eylese Hind ve Bekir hisse-i merkûmeyi şufa ile ne vechile alurlar? Elcevab: Berâber.", Çatalcalı Ali Efendi/Demirtaş, H. Necati (2014) Açıklamalı Osmanlı Fetvaları: Fetâvâ-yı Ali Efendi, cild-i sâni, 1. Baskı, İstanbul, Kubbealtı, s. 362. MAA, m. 215, 1088; Ali Haydar, C. I, s. 211-212, C. III, s. 165-166; Hacak (2006b), s. 151; Bilmen, C. VII, s. 69; Kâhya, s. 19.

37 Hacak (2006b), s. 151.

38 "Karındaşlar olan Zeyd ve Amr birbirine muttasıl olub kâbil-i kısmet olmayan üç göz değirmene a'le'l-iştirâk malikler iken Zeyd, ol değirmenlerden hisse-i şâyiâsını Amr'a hibe ve teslim eylese hibe-i mezbûre sahih olur mu? El-cevab: Olur.", Çatalcalı/Demirtaş, s. 234. 
bağışlanana teslim edilmesi gerektiği görüşündedirler ${ }^{39}$. Bununla birlikte Maliki, Şafii ve Hanbeli mezheplerine mensup hukukçulara göre ise taksimi mümkün olsun ya da olmasın pay sahiplerinin müşterek maldaki hisselerini diğer pay sahiplerinden birine ya da üçüncü kişilere bağışlamaları mümkündür ${ }^{40}$.

Öte yandan Maliki, Şafii ve Hanbeli mezheplerine göre müşterek malın taksime elverişli olsun ya da olmasın rehin olarak verilmesi de mümkündür. Çünkü bu mezheplere mensup hukukçulara göre bir malın rehin verilmesinden maksat, gerektiğinde rehin malın satılmasıyla alacaklının alacağının ödenmesidir. Dolayısıyla müşterek malın satılması da mümkün olduğundan rehin olarak verilmesi de caizdir. Buna karşın Hanefilik mezhebinde müşterek malda pay sahiplerinden birinin kendi hissesini diğerlerinden ayırıp alacaklıya teslim etmesi mümkün olmadığından rehin olarak da verilmeyeceği kanaati hâkimdir ${ }^{41}$.

İslam-Osmanlı eşya hukuku hükümleri çerçevesinde müşterek mülkiyetle malik olunan bir malı ortaklardan birinin kendi payını diğerlerine kiraya vermesi İslam hukukçularının tamamına göre caiz olduğu halde, üçüncü şahıslara kiraya verilmesi hususunda ise görüş ayrılığı vardır. Zira Hanefi ve Hanbeli mezheplerine mensup hukukçulara göre ortaklardan birinin müşterek maldaki hissesini üçüncü şahıslara kiralaması caiz değildir. Çünkü menfaatin teslimi mümkün olmadığından söz konusu hissenin de üçüncü kişilere teslim edilmesi mümkün değildir. Ancak bu hissenin diğer ortaklara kiraya verilmesi halinde hissenin teslimi mümkün olduğu için kiralaması da mümkün olur ${ }^{42}$.

39 "Hind, kâbil-i kısmet olan menzilinin nısfını şâyian zevci Zeyd'e hibe ve şâyian teslim eylese hibe-i mezbûre sahih olur mu? El-cevab: Olmaz.", Çatalcalı/Demirtaş, s. 236.

40 MAA, m. 55; Ali Haydar, C. I, s. 79-81; Hacak (2006b), s. 152; Ekinci (2017), s. 477; Ekinci (2016), s. 444; Bilmen, C. IV, s. 244; Kâhya, s. 21.

${ }^{41}$ Ali Haydar, C. II, s. 164; Hacak (2006b), s. 151-152; Hacak, Hasan/Çalış, Halit (2007) "Rehin”, Türkiye Diyanet Vakfi İslam Ansiklopedisi, C: 34, s. 539; Kâhya, s. 20-21.

42 MAA, m. 429; Ali Haydar, C. I, s. 432-433; Hacak (2006b), s. 151; Çelen, s. 72-73; Türkmen, s. 36; Kâhya, s. 20. 
Öte yandan müşterek bir malın vakfı hususunda Hanefi mezhebine mensup hukukçular arasında da görüş ayrılı̆̆ı vardır. Zira İmam Muhammed vakıfta teslimi şart koştuğundan müşterek maldaki hissenin vakfedilebilmesi için söz konusu malın taksime elverişli olmaması gerekmektedir. Çünkü müşterek malın taksimi mümkün ise öncelikle taksim işleminin gerçekleştirilip sonrasında pay sahibinin kendi hissesini vakfetmesi gerekir. Buna karşın Ebu Yusuf, taksimi mümkün müşterek maldaki hissenin de vakfedilebileceği kanaatindedir ${ }^{43}$. Taksimi elverişli olmayan müşterek maldaki hissenin vakfı ise Hanefilere göre ittifakla caizdir ${ }^{44}$. Bununla birlikte Malikiler taksimi mümkün olan müşterek maldaki hissenin vakfını caiz gördükleri halde, taksimi mümkün olamayan müşterek maldaki hissenin vakfını ise caiz görmezler. Buna karşın Şafii ve Hanbeli mezheplerine mensup İslam hukukçuları ise taksimi mümkün olsun ya da olmasın müşterek maldaki hissenin vakfedilmesini sahih kabul ederler ${ }^{45}$.

İslam-Osmanlı eşya hukukunda müşterek maliklerden her birinin müşterek maldaki hissesi diğer maliklerin elinde vedia ${ }^{46}$ hükmünde olup pay sahiplerinin birbirlerine karşı sorumlulukları vedia akdi çerçevesinde

43 “... menzil-i mezkûr kābil-i kısmet olup ve hazret-i İmâm Muhammed b. Hasan eş-Şeybân̂̂ mezheb-i şerîfleri üzere ba'zı meşâyih-i kirâm katlarında kābil-i kısmet olan akār$\imath$ müşâ'ın müşâ'an vakfı câiz olmamağla vakf-ı mezbûrdan rücû've menzil-i mezkûrdan hisse-i mezkûremi mülküme istirdâd ederim, mütevellî-i mezbûrun kasr-ı yedine tenbîh olunmak matlûbumdur dedikde mütevellî-i mezbûr cevâb-ı bâ-savâba şürû‘ edip gerçi akār$\imath$ müşấ kābil-i kısmetin müşâ'an vakfı ba'zı meşâyih-i kirâm katında câiz değildir, lâkin fâzıl-ı samadânî Eb̂ิ Yusuf eş-şehîr bi'l-imâmı sânî hazretleri mezheb-i şerîfleri üzere ba'zı meşâyih-i müteahhırîn-i kirâm katında kavl-i müftâ-bih üzere câizdir deyü ...”, Yılmaz, Coşkun (editör) (2019) İstanbul Kadı Sicilleri 79 Davud Paşa Mahkemesi 1 Numaralı Sicil (H. 1196-1197 / M. 1782-1783), İstanbul, İstanbul Büyükşehir Belediyesi Kültür A.Ş Yayınları, s. 175-177; Hüküm No: 141 [20M/b-2].

44 Akgündüz, Ahmet (1996) İslam Hukukunda ve Osmanlı Tatbikatında Vakıf Müessesesi, 2. Baskı, İstanbul, Osmanlı Araştırmaları Vakfı, s. 196-197; Hacak (2006b), s. 152; Çelen, s. 74-75; Kâhya, s. 103-105.

45 Akgündüz, s. 196-197; Çelen, s. 74-75; Kâhya, s. 105.

46 Korunması amacıyla bir başkasına bırakılan mal ve bu malı bırakmak üzere yapılan akit anlamına gelen "vedîa" hakkında ayrıntılı bilgi için bakınız: Yıldırım, Mustafa (2012) "Vedîa”, Türkiye Diyanet Vakfı İslam Ansiklopedisi, C: 42, s. 596-598. 
değerlendirilir ${ }^{47}$. Öte yandan müşterek bir malda pay sahiplerinden birinin kendine ait hisseyi karz $^{48}$ ya da ariyet ${ }^{49}$ olarak üçüncü kişilere verebileceği hususunda İslam hukukçuları arasında görüş birliği vardır ${ }^{50}$.

İslam-Osmanlı hukukunda pay sahiplerinin müşterek mal üzerindeki tasarruf yetkilerine ilişkin olarak verdiğimiz bu bilgilerin ardından müşterek mülkiyeti sona erdiren halleri incelemekte yarar vardır.

\section{MÜŞTEREK MÜLKIYYETİN SONA ERMESI}

İslam-Osmanlı eşya hukuku hükümleri çerçevesinde müşterek mülkiyet bazı hukuki işlem veya olayların sonucunda meydana geldiği gibi sona ermesi için de bazı hukuki işlem veya olayların gerçekleşmesi gerekmektedir. Bu kapsamda müşterek mülkiyet ortaklardan biri veya bir kaçı için sona ermiş olabileceği gibi müşterek ortaklık tamamen de ortadan kalkmış olabilir. Pay sahiplerinden biri veya bir kaçının müşterek mal üzerindeki mülkiyet hakkı sona ermişse, bu ortak veya ortakların ortaklıktan ayrıldığı kabul edilir. Binaenaleyh satım ya da bağışlama sözleşmesi gibi mülkiyeti nakledici nitelikteki bazı hukuki işlemler müşterek maliklerden biri ya da bir kaçı için mülkiyet hakkını sona erdirebileceği gibi vakıf malını vakfeden, ölüm de ölen ortak açısından müşterek maldaki mülkiyet hakkını sona erdiren sebeplerdir.

Bununla birlikte müşterek malın yok olması, istimlâk $k^{51}$ edilmesi, cebri satış ${ }^{52}$ ya da malın kendisinin veya menfaatlerinin taksimi müşterek

47 MAA, m. 1087; Ali Haydar, C. III, s. 164-165; Türkmen, s. 36.

48 Geri ödenmek üzere verilen mal ya da birine ödünç/borç verme anlamına gelen "karz" hakkında ayrıntılı bilgi için bakınız: Apaydın, H. Yunus (2001) "Karz", Türkiye Diyanet Vakfı İslam Ansiklopedisi, C: 24, s. 520-525; Şener, Mehmet (1989) "İslam Hukukunda Karz-1 Hasen”, Dokuz Eylül Üniversitesi İlahiyat Fakültesi Dergisi, S: 6, s. 391-403.

49 Bir süre kullanmak üzere bir kimseye karşılıksız olarak verilen mal anlamına gelen "âriyet" hakkında ayrıntılı bilgi için bakınız: Gözübenli, Beşir (1991) “Âriyet”, Türkiye Diyanet Vakfı İslam Ansiklopedisi, C: 3, s. 379-380.

50 Hacak (2006b), s. 152; Kâhya, s. 19.

51 Özel mülkiyete tabi gayrimenkul bir malın kamu yararı amacıyla bedeli ödenerek kamulaştırılması anlamına gelen "istimlâk" hakkında ayrıntılı bilgi için bakınız: Aktan, Hamza (2001) “İstimlâk”, Türkiye Diyanet Vakfı İslam Ansiklopedisi, C: 23, s. 364-366. 
maliklerin tamamı için müşterek maldaki mülkiyet haklarının sona ermesine yol açan, dolayısıyla müşterek mülkiyeti sona erdiren sebeplerdir. Keza müşterek maliklerin uzlaşarak müşterek malı hep birlikte satmaları, bağışlamaları, vakfetmeleri ya da sadaka olarak vermeleri de müşterek mülkiyeti sona erdiren sebeplerdendir ${ }^{53}$.

Biz de çalışmamızın bundan sonraki bölümünde müşterek mülkiyeti sona erdiren sebeplerden taksim hususunu ele alıp inceleyeceğiz.

\section{II. İSLAM-OSMANLI HUKUKUNDA MÜŞTEREK MÜLKIYYETIN TAKSIMİ}

İslam-Osmanlı eşya hukuku hükümleri çerçevesinde müşterek mülkiyetin taksimi bir eşyanın ayn adı verilen maddi yapısının taksimi ve malın maddi yapısı aynen kalmakla birlikte bu maldan elde edilen menfaatlerin taksimi olmak üzere iki şekilde olmaktadır ${ }^{54}$. Bununla birlikte klasik İslam hukuku kaynaklarında "taksim" kavramı ile esasen kastedilen müşterek malın maddi yapısının paylaşılması olup, menfaatlerin taksimi ise "muhâyee" kavramı ile ifade edilmektedir.

\section{A. MÜŞTEREK MALIN TAKSIMII}

$\mathrm{Bu}$ başlık altında taksimin tanımı yapılarak hukuki niteliği, hukuki dayanağı, taksim çeşitleri, taksim için gerekli şartlar ve taksim işleminin hükümleri üzerinde durulacaktır.

52 Maliki ve Hanbeli mezheplerine göre taksime elverişli olmayan müşterek malda ortaklardan bir veya bir kaçının malın satılmasını istemesine karşın diğerlerinin buna yanaşmaması üzerine müşterek malın cebri satış yoluyla satılması ve bedelinin pay sahiplerine bölüştürülmesi mümkündür. Borcunu ödemekten imtina eden kişinin hacze kabil mallarının, alacaklının talebiyle, mahkeme kararıyla satışı anlamına gelen "cebri satış" hakkında ayrıntılı bilgi için bakınız: Atar, Fahrettin (1990) İslam İcra ve İflas Hukuku, 1. Baskı, İstanbul, Marmara Üniversitesi İlahiyat Fakültesi Vakfı Yayınları, s. 155 vd.

53 Cin/Akgündüz, s. 676-677; Karaman, C. III, s. 52-54; Avcı, s. 513; Çelen, s. 82 vd.

54 Çelen, s. 82. 


\section{Tanımı ve Hukuki Niteliği}

Sözlük anlamı olarak "ayırmak, paylaşmak, paylaştırmak, bölüşmek, bölüştürmek ve dağıtmak” gibi anlamlara gelen taksim bir İslam hukuku terim olarak ise müşterek mallarda ortakların paylarının belirli hale getirilmesi ya da Mecellenin de ifadesiyle şayi hisselerin tayin edilmesidir. Bu kapsamda klasik İslam hukuku literatüründe pay anlamında "kısım, miksem, kasîm" kelimeleri kullanılırken müşterek malı paylaştıran kişi anlamında ise "kassam, kâsım” kelimeleri kullanılmıştır ${ }^{55}$.

İslam hukukçuları arasında ihtilaflı bir mesele olmakla birlikte hukuki niteliği itibariyle taksim, müşterek maldaki payları birbirinden ayırmaktan (ifraz) ve birini öbürü ile değiştirmekten (mübadele) ibarettir. Nitekim neticesi itibariyle müşterek mal üzerinde şayi olan hisselerin ayrılmasına yol açan taksim işlemi bu yönüyle bir ifrazdır. Bununla birlikte müşterek malda pay sahiplerinin mülkiyet hakkı malın tamamı üzerinde kendi hissesi oranındadır. Bu sebeple taksim işlemi sonucunda her bir ortak kendi payına düşen hisseden diğer ortakların vazgeçmelerine karşıllk, onlara düşen hisselerdeki mülkiyet hakkından feragat etmektedir. Dolayısıyla bu cihetten bakıldığında taksim işleminin mübadele özelliği taşıdığı söylenebilir ${ }^{56}$.

Müşterek mülkiyete konu teşkil edip, ortaklar arasında paylaştırılacak malın misli ${ }^{57}$ ya da kıyemi ${ }^{58}$ oluşuna göre de taksim işleminin ifraz ve

55 MAA, m. 1114; Ali Haydar, C. III, s. 201-202; İbrahim Halebî (t.y.) Mevkûfât Mültekâ Tercümesi, c. IV, (Şerheden: Mehmed Mevkûfâti, Sadeleştiren: Ahmed Davudoğlu), İstanbul, Sağlam Kitabevi, s. 25; Aktan, Hamza (2002) "Kısmet”, Türkiye Diyanet Vakfı İslam Ansiklopedisi, C: 25, s. 497-498; Sağlam, s. 370; Çelen, s. 83; Kâhya, s. 22-23.

56 MAA, m. 1116; Ali Haydar, C. III, s. 203-204; Kâhya, s. 24; Elmalılı Muhammed Hamdi Yazır (1997) Alfabetik İslam Hukuku ve Fıkıh Istılahları Kamusu, C. III, (Hazırlayan: Sıtkı Gülle), İstanbul, Ensar Neşriyat, s. 253.

57 Çarşı ve pazarda birimleri arasında değer farkı olmayacak şekilde benzerleri bulunan mal anlamına gelen "mislî mal" hakkında ayrıntılı bilgi için bakınız: Hacak, Hasan (2001) "Mislî”, Türkiye Diyanet Vakfı İslam Ansiklopedisi, C: 30, s. 187-188; Cin/Akgündüz, s. 671; Aydın (2014), s. 334-335; Ekinci (2017), s. 474.

58 Çarşı ve pazarda benzeri olmayan ya da benzeri olmakla birlikte birimleri arasında değer farkı olan mal anlamına gelen "kıyemî mal" hakkında ayrıntılı bilgi için bakınız: Gözübenli, 
mübadele yönleri farklılık gösterebilir. Zira misli mallar ölçülebilen, tartılabilen veya bu hükümde olan şeylerden oluştuğundan pay sahipleri karz veren kişi konumunda olup müşterek malın taksimi ile verdiğini aynıyla geri almış gibi kabul edilir. Bu sebeple İslam hukukçularının ekserisine göre misli mallarda ifraz özelliği mübadeleye göre daha ağırdır. Buna karşın hayvan, elbise veya gayrimenkul gibi kıyemi mallarda ise misli malların aksine mübadele yönü daha baskındır. Çünkü bu çeşit malların birimleri arasında farklılık bulunduğundan taksim işlemi ile müşterek maliklere düşen payların kendi haklarının aynı olduğunu düşünmek mümkün değildir ${ }^{59}$.

Müşterek malın taksimi işlemi ifraz özelliği taşıyor ise bu durumda ortaklardan birinin, diğer ortakların bulunmadığı bir zamanda kendi hissesini alması caiz olduğundan müşterek malın misli olması halinde pay sahiplerinden her biri diğerlerinin yokluğunda taksimi gerçekleştirebilir. Keza ortaklardan birinin taksimden imtina etmesi halinde mahkeme kararı ile bu ortağın taksime zorlanması da mümkündür. Yine birden fazla kişi misli bir malı birlikte satın alıp aralarında taksim ettikten sonra her birisinin kendisine düşen hisseyi almış olduğu fiyattan daha fazlasına satması caizdir. Keza ifraz niteliğindeki taksim işlemlerinde yalnızca ayıp muhayyerliği söz konusu olur ${ }^{60}$.

Taksim işleminin mübadele yönünün daha ağır olması halinde ise müşterek maliklerden birinin diğer maliklerin yokluğunda müşterek maldan kendi hissesini alması mümkün değildir. Pay sahiplerinden herhangi birisinin taksimden imtina etmesi durumunda ise aynı cins mallarda taksime cebredilmesi mümkün olduğu halde farklı türden mallarda taksimden kaçınan pay sahibinin taksime zorlanması mümkün değildir. Keza mübadele özelliği taşıyan bir taksimde ortaklardan birinin kendisine düşen hisseyi kâr elde ederek satması da caiz değildir. Bununla birlikte mübadele niteliğindeki taksim işlemlerinde paylaştırılacak kıyemi mallar farklı cins iseler ayıp, şart ve

Beşir (2002) "Kıyemî”, Türkiye Diyanet Vakfı İslam Ansiklopedisi, C: 25, s. 540-541; Cin/Akgündüz, s. 671; Aydın (2014), s. 334-335; Ekinci (2017), s. 474. MAA, m. 1117-1118; Ali Haydar, C. III, s. 204-205; Elmalılı, C. III, s. 254-255; Halebî, C. IV, s. 25.

60 Halebî, C. IV, s. 25; Ali Haydar, C. III, s. 204; Kâhya, s. 26. 
görme muhayyerlikleri taksime dâhil olduğu halde aynı tür malların taksiminde ise ayıp muhayyerliğinin taksime dâhil olacağı hususunda İslam hukukçuları arasında ittifak olmakla birlikte diğer iki muhayyerliğin ise taksim kapsamında olup olmadığı konusu tartışmalıdır ${ }^{61}$.

\section{Hukuki Dayanağı}

İslam-Osmanlı eşya hukukunda ortaklığ sona erdiren sebeplerden birinin oluşması ya da pay sahiplerinden birinin kendi hissesinden tek başına yararlanmayı istemesi sonucu uygulanan taksim işleminin hukuki dayanağını Kur'an-1 Kerim'de yer alan çeşitli ayetler ve Hz. Peygamber'in sünneti oluşturmaktadır.

Nisa suresinde yer alan "(Mirastan payı olmayan) yakılar, yetimler ve yoksullar miras taksiminde hazır bulunurlarsa bundan onları da rizıklandırın ve onlara güzel söz söyleyin." ${ }^{\prime 2}$ şeklindeki ayette her ne kadar yalnızca miras taksiminden söz edilse de bu hüküm yalnızca miras taksimine mahsus olmayıp bütün müşterek malların taksimini kapsamaktadır. Keza bir başka ayette ise ganimetlerin paylaştırılması ile ilgili olarak "İki ordunun birbiri ile karşılaştı̆̆ı gün (Bedir Savaşında) kulumuza indirdiğimize inanmışsanız, bilin

${ }^{61}$ Halebî, C. IV, s. 26; Ali Haydar, C. III, s. 205-206; Kâhya, s. 26-27; “... huzûrlarında 'akd meclis-i şer'i nebevi ettikde müteveffa-yı mezbûr Savran oğlu Pavlı Harlanbi oğlu sağir Mihlaki beynelerinde nefsiyet üzere müssterek mahalle-i mezbûrede vâki' etrâfi erbâ'sı Kara Veysel hanesi ve Nakurlu oğlu ve pazarlı oğlu bağçeleri ve tarik-i ile mahdûddur terbi'en beşyüz zirâ' bir bâb mülk menzillerini ikdamlarda milleti merkûme beyinlerine bi't-terâzi nısfiyet üzere taksim ve ifrâz ve ta'yîn hudûd eylediklerinden merkûm Kara Veysel hanesi ve Ankorlu oğlu ve Pazarlı oğlu bağçeleri ve tarik ile mahdûd bir odalı üçyüz elli zira' arsa ma'a arsa haneye müteveffa-yı mezbûr Savran oğlu Pavli vereseleri hisselerine ve Savran oğlu vereseleri hanesi ve tarik ile mahdûd yüz elli zira' bir odal hane merkûm Mahlaki'nin müstekıllen hissesine isâbet ile her birileri hisse-i müfrezesini bi'l-asâle ve bi'l-vesâya aht ve zabt eyledikleri ba'de'l-beyân yedine taksîm meşrûh üzere ... (?) oldukları meclis-i ma'kûd mezkûrda şifâhen mahâllinde lede'şşuhûd takrîr ve tasdîk eylediklerini kâtib-i mûma-ileyh mahâllinde ketb ve tahrîr ve meb'an meb'ûs e'imme-i sa'ire ile meclis-i şer'i gelüb alî vukû' inhâ ve takrîr eylediği bi'l-iltimâs huzûr âlilerine i'lâm olundu. (15 Cemaziyelevvel 1320/20 A ğustos 1902)”, Aydın, Münevver (2019) “185 Numaralı Denizli Şer’iyye Sicil Defterinin Transkripsiyonu ve Değerlendirmesi (1875-1883)” (Yüksek Lisans), Afyon Kocatepe Üniversitesi, Sosyal Bilimler Enstitüsü, s. 578-579.

Nisa, $4 / 8$. 
ki ganimet olarak aldığınız herhangi bir şeyin beşte biri Allah'a, Resûlüne, onun akrabalarına, yetimlere, yoksullara ve yolculara aittir. ${ }^{{ }^{\prime 63} 3}$ şeklindeki hükümle ayn mülkiyetinin taksiminin meşruluğuna zımni olarak işaret edilmektedir. Çünkü söz konusu ayet ile savaşta ele geçirilen ganimetlerin beşte biri, geriye kalan beşte dördünden ayrılarak nasıl tasarruf edileceği hususu bildirilmiştir ${ }^{64}$.

Taksim işleminin hukuki meşruiyeti İslam hukukunun Kur'an-1 Kerim'den sonra ikinci sıradaki kaynağı olan Hz. Peygamber'in sünneti ile de sabittir. Nitekim Hz. Peygamber'e ait 'Cahiliye döneminde taksim edilmiş her mal, taksim edildiği şekil üzeredir. İslam döneminde yapılan taksimat, İslam'ın esaslarına göredir. ${ }^{165}$ ve "Her hak sahibine hakkını verin. ${ }^{\prime 66}$ şeklindeki hadisler müşterek mülkiyetin taksiminin sünnetteki delillerini oluşturmaktadır. Keza Hz. Peygamber'in Hayber ve Huneyn'de alınan ganimetleri savaşa katılanlar arasında taksim etmesi ve sahabeler arasında mirasları paylaştırması da taksimin sünnetteki hukuki dayanaklarındandır ${ }^{67}$.

Öte yandan Mecelle-i Ahkâm-1 Adliyye ${ }^{68}$ ve 1858 tarihli Arazi Kanunnamesi ${ }^{69}$ müşterek malın taksiminin Osmanlı hukukundaki yasal dayanakları arasında gösterilebilir.

\section{3. Çeşitleri}

İslam eşya hukuku hükümleri çerçevesinde taksimin çeşitleri açısından mezhepler arasında ihtilaf olmakla birlikte netice itibariyle mezheplerin her birindeki ayrım diğer mezheplerde yer alan ayrımlara ilişkin tüm hükümleri bünyesinde barındırmaktadır. Bu kapsamda Osmanlı Devleti'nin de resmi mezhebi olan Hanefi mezhebine mensup hukukçular taksimi kısmet-i cem ve kısmet-i tefrik şeklinde ikiye ayırıp her iki taksim türüne de ortakların rızasıyla ya da mahkeme kararıyla yapılmasına göre farklı hükümler bağlamışlardır. Hanbelilik mezhebine mensup hukukçular da Hanefiler gibi

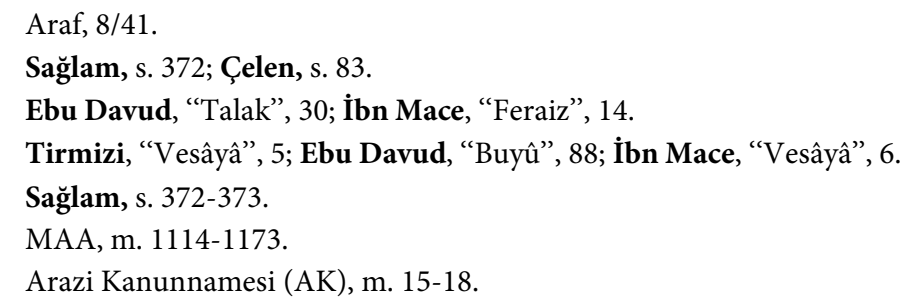


taksimi müşterek maliklerin rızalarının bulunup bulunmamasına göre rıza veya mahkeme kararıyla taksim şeklinde ikiye ayırıp incelemişlerdir. Bununla birlikte Maliki ve Şafii mezheplerinde taksim birbirinden farklı isimler altında üçe ayrılıp incelenmiştir. Bu çerçevede Malikiler taksimi kısmet-i rıza, kısmeti kura ve kısmet-i muhâyee şeklinde isimlendirirlerken Şafiiler ise kısmet-i ecza, kısmet-i tadil ve kısmet-i red olarak adlandırmışlardır ${ }^{70}$.

Bununla birlikte müssterek malın taksimi konusunda mezheplerin yapmış olduğu tasnifler de nazara alınarak taksim işleminin çeşitli açılardan farklı tasniflere tabi tutulması mümkündür. Bu kapsamda taksim; pay sahiplerinin iradeleri açısından kısmet-i rıza ve kısmet-i kaza şeklinde ikiye; müşterek malın paylaştırılması sonucunda eşitlemeye ihtiyaç duyulup duyulmamasına göre kısmet-i ecza, kısmet-i tadil ve kısmet-i red olmak üzere üçe; paylaştırılacak malın bir ya da birden fazla olması açısından kısmet-i cem ve kısmet-i tefrik olmak üzere ikiye ayrılır.

a. Pay Sahiplerinin İradeleri Açısından Taksim

Pay sahiplerinin iradeleri açısından müşterek malın taksimi kısmet-i rıza ve kısmet-i kaza olmak üzere ikiye ayrılmaktadır. Müşterek maliklerin tamamının talebi ya da içlerinden bir kısmının istemesi diğerlerinin de buna muvafakat etmesi sonucunda pay sahiplerinin rızasıyla yapılan taksim işlemine kısmet-i rıza adı verilir. Bu durumda taksim işlemi mahkemeye intikal etmeden tarafların uzlaşmasıyla yapılabileceği gibi ortakların hepsinin talebi ve rızasıyla hâkim tarafından da akdedilebilir ${ }^{71}$. İslam-Osmanlı eşya hukuku hükümleri çerçevesinde karşılıklı rıza ile yapılan taksimin bu türü bir çeşit sözleşme olarak kabul edildiğinden her sözleşmede olduğu gibi bunun da unsurları icap ve kabuldür. Müşterek malikler arasında çocuk veya akıl hastası gibi eksik eda ehliyetine sahip kişilerin olması halinde bunların veli ya da vasileri taksim işlemini gerçekleştirebilir. Bununla birlikte eksik eda ehliyetine sahip pay sahiplerinin veli ya da vasileri yoksa hâkim tarafından tayin edilen

Çelen, s. 85; Kâhya, s. 28.

71 MAA, m. 1121; Ali Haydar, C. III, s. 208; Bilmen, C. VII, s. 58; Cin/Akgündüz, s. 676; Sağlam, s. 372; Karaman, C. III, s. 52; Çelen, s. 85. 
vasinin nezaretinde taksim yapılır ${ }^{72}$. Öte yandan aynı cins veya farklı cinsten mallar müşterek maliklerin rızası ile paylaştırılabileceği gibi müşterek malın misli veya kıyemi olmasının da kısmet-i rıza üzerinde herhangi bir etkisi yoktur. Keza Hanefilere göre müşterek malın paylaştırılması karşılıklı rıza ile yapıldıktan sonra bu taksim ortaklardan birine ya da hepsine zarar vermiş olsa bile taksim işlemi hukuki olarak geçerlidir ${ }^{73}$.

Müşterek maliklerden biri ya da bir kısmının müşterek malın taksimini talep etmesine karşın diğer pay sahiplerinin paylaşımdan kaçınması halinde taksimi isteyen tarafın mahkemeye müracaat etmesi sonucu hâkim kararıyla gerçekleşen taksim çeşidine kısmet-i kaza adı verilir. Bu durumda paylaştırma işlemi hâkim veya görevlendirdiği bir kişi tarafından cebren yapıldığından kısmet-i kaza yerine cebri taksim adı da kullanılmaktadır ${ }^{74}$. Kısmet-i kaza yolu

72 "Zeyd, fevtolub evlâd-ı sığârı ile evlâd-ı kibârını terkitdikde evlâd-ı kibâr, evlâd-ı sığâr içün hâkime vasî nasbitdürüb kâbil-i kısmet olan terekeyi kısmet itdürmege kâdir olur mu? Elcevab: Olur.", Çatalcalı/Demirtaş, s. 367.

73 MAA, m. 1128; Ali Haydar, C. III, s. 218-219; Halebî, C. IV, s. 26; Aktan (2002), s. 498; Kâhya, s. 28-29.

74 MAA, m. 1122; Ali Haydar, C. III, s. 208-209; Bilmen, C. VII, s. 58, 143; Halebî, C. IV, s. 26; Aktan (2002), s. 497; Cin/Akgündüz, s. 676-677; Karaman, C. III, s. 52; Sağlam, s. 374375; “... mahmiye-i İstanbul'da Âbid Çelebi mahallesinde vâki' iştirâken müteveffâ Derviş Mehmed Efendi veresesine müntakil bir tarafdan Merdümiye Medresesi arsası ve bir tarafdan ve havâsı hissedârlardan sahibe-i arzuhâl Şerife Âişe Hatun mülkü ve tarafeyni tarîk-ı âm ve hâs arsası mukāta'alı vakıf ve binâsı mülk bir bâb kürkçü dükkânı ve muttasıl oda ve manav dükkânını müştemil mahâll-i nizâ'’n üzerine varıp cerîdede mastûrü'l-esâmî Müslimîn huzûrunda akd eylediği meclis-i şer'de mezbûre Şerife Âişe Hatun zâtı ba'de'tta'rîfi'ş-şerî̀ kendi tarafindan asâleten ve vâlidesi Şerife Sâliha Hatun tarafindan vekîle-i müseccelesi olmağla vekâleten er karındaşı ve şerîki Lütfullah ile vâlidesi ve hâl-i sıgārında vasiyyesi Zeliha Hatun muvâcehesinde zikrolunan beynimizde müşterek olmağla müşấan tasarrufa mâni' birbirimiz ile her bâr icâre nizâ'ı vâki' olmağın şer'le keşif olunup käbil-i kısmet olduğu hâlde herkesin hissesi ifrâz ve kendiye tahsîs olunmak matlûbumdur deyü da'vâ ve müdde'âsına mutâbık bir kıt'a fetvâ-yı şerîfe ibrâz edip ve lâkin mezbûr Lütfullah ve vasiyyesi merkūme Zeliha zikrolunan dükkânlar evvelen kābil-i taksîm ve sâniyen mümkinü'l-intifâ' değildir deyü nizâ've kısmetinden tereddüd ve imtinâ' etmeğin mi'mârân-ı mezbûrân zikrolunan dükkânları ba'de'l-mesâha mecmî'u tûlen ve arzen bi-hesâb-ı terbî̀ altmış altı buçuk zirâ‘ olup otuz bir zirấ i işbu kürkçü dükkânına tahsîs ve bâkī yirmi iki buçuk zirâ‘ oda ile on üç zirâ' manav dükkânı başka ifrâz olundukda kābil-i kısmet ve hisselerden intifâ‘ mümkündür deyü haber verdikleri ecilden ber-mûceb-i fetvâ-yı şerîfe 
ile müşterek mülkiyetin taksim edilebilmesi için pay sahiplerinden biri veya bir kısmının mahkemeye başvurması ve müşterek malın taksime elverişli mallardan olması gerekir ${ }^{75}$. Osmanlı Devleti uygulamasında hâkim, taksim edilecek müşterek malın ekonomik değerinin tespitinde ve fiziki olarak taksime elverişli olup olmadığı hususunda bilirkişiden istifade etmiştir. $\mathrm{Bu}$ kapsamda bilirkişiler yalnızca müşterek malın ekonomik değerini ve taksime elverişli olup olmadığını tespit ile görevli olmayıp, taksime elverişli bulunan malın nasıl bölüştürülebileceği hususunda da görev ifa etmişlerdir ${ }^{76}$. Öte yandan mahkeme kararı ile paylaştırılacak malın misli ya da kıyemi olmasının taksim üzerinde herhangi bir etkisi olmamakla birlikte söz konusu malların farklı türden olması halinde ise hâkimin tarafları taksime zorlaması caiz değildir ${ }^{77}$. Ayrıca müşterek malın cebren paylaştırılması ortakların hepsine zarar veriyorsa kısmet-i kaza mümkün olmamakla birlikte taksimi talep eden

taksîm ve mukaddemâ verese-i mezbûrûn beyninde bâ-hüccet-i şer'iye taksîm olunan menzilden herbirinin hisselerine isâbet eden sihâm-ı mu'ayyeneye tatbîk ve kat'à li'n-nizấ mezbûr Lütfullah cânibi tercîh olunmağın zikrolunan kürkçü dükkânı köşebaşında mevki'i şerîf ve mu'teber ve revâc ve rağbeti gayriden ezyed ve evfer olmağla hisse-i mu'ayyenesi'çün temyîz ve ifrâz olunup bâkī zikrolunan oda ve manav dükkânı müşâ'an müdde'iye-i mezbûre Şerife [13a] ile müvekkile ve vâlidesi merkūme Şerife Sâliha Hatun hisselerine kalmağla asâleten ve vekâleten kabûl etmeğin vech-i meşrûh üzere tarafeynin hisselerine had ta'yîn ve beynlerine alâmet-i fâsıla vaz' olunduğunu ...", Yılmaz, Coşkun (editör) (2019) İstanbul Kadı Sicilleri 73 Bab Mahkemesi 197 Numaralı Sicil (H. 1162-1163 / M. 1749-1750), İstanbul, İstanbul Büyükşehir Belediyesi Kültür A.Ş Yayınları, s. 143-144, Hüküm No: 86 [12b-3].

$75 \mathrm{AK}, \mathrm{m} .15$; "Zeyd-i müteveffânın veresesinden Hind ve Zeyneb terekeden olub kısmet olunduğu takdirde herkes hissesiyle intifa' mümkün olan menzil ve bağçeyi hâkime kısmet itdürüb hisselerini almak istedüklerinde sâir verese mücerred: 'Birkaç sen a'le'l-iştirâk tasarruf eyledik!' deyu kısmetden men'e kâdir olurlar mı? El-cevab: Olmazlar.”, Çatalcali/Demirtaş, s. 369.

76 Kılınç, Ahmet (2019) Osmanlı Yargılama Hukukunda Bilirkişilik, 1. Baskı, Ankara, Adalet Yayınevi, s. 174-178.

77 MAA, m. 1129-1130; Ali Haydar, C. III, s. 219-223; Bilmen, C. VII, s. 142; Halebî, C. IV, s. 26; Aktan (2002), s. 497. 
ortak veya ortaklara fayda sağladığı halde diğerlerine zarar veriyorsa hâkim taksime hükmedebilir ${ }^{78}$.

b. Eşitlemeye İhtiyaç Duyulup Duyulmaması Açısından Taksim

Müşterek mülkiyetin taksimi sonucunda ortaklara düşen hisseler bazen şekil ve kıymet bakımından birbirine eşit olduğu halde bazen de bu denklik sağlanamayabilir. Şayet taksim işlemi sonucunda ortaklar arasında eşitlik sağlanamamışsa müşterek malın kendi içerisinde uygulanan bazı işlemlerle ya da dışarıdan bazı ilaveler yapılması suretiyle müşterek maliklere düşen paylar denkleştirilmeye çalışılır. Dolayısıyla paylaştırma sonucunda eşitlemeye ihtiyaç duyulup duyulmamasına göre taksim kısmet-i ecza, kısmet-i tadil ve kısmet-i red olmak üzere üçe ayrılır.

Müşterek malın taksimi neticesinde ortaklara düşen payların hem şekil hem de kıymet bakımından birbirine eşit olduğu taksim çeşidine kısmet-i ecza adı verilmektedir. Kısmet-i ecza esasen misli mallarda söz konusu olmakla birlikte aynı türden kıyemi malların da bu şekilde paylaştırılması mümkündür. Kısmet-i eczanın uygulanabileceği bir müşterek malın taksimi sırasında ortaklardan biri paylaştırmadan kaçınacak olursa, kaçınan tarafa bir zararı dokunmadığı sürece cebren taksime karar verilebilir ${ }^{79}$.

Öte yandan müşterek malın taksimi neticesinde ortaklara düşen payların niteliği itibariyle aralarında bir farklılık olmamakla birlikte değerleri açısından birbirinden farklı olması durumuna kısmet-i tadil adı verilir. Örneğin suya veya yola yakınlık, verimlilik ya da parçalardan birinin fındıklık diğerinin ise cevizlik olması gibi sebeplerle parçaları arasında farklılık bulunan arazilerin taksiminde kısmet-i tadil söz konusu olur. Kısmet-i tadil adı verilen bu tür taksimde müşterek malın niteliği bakımından eşit paylara bölünmesinden ziyade değerine göre birbirine denk parçalara bölüştürülmesi amaçlanır. Taksimin bu türünde de pay sahipleri açısından bir zarar söz

78 MAA, m. 1139-1141; Ali Haydar, C. III, s. 230-233; Bilmen, C. VII, s. 142-143; Kâhya, s. 29-30.

79 Kâhya, s. 30-31. 
konusu değilse imtina eden pay sahiplerinin taksime zorlanmaları mümkündür ${ }^{80}$.

Diğer taraftan müşterek malın taksiminde paylar arasında eşitlik sağlanamayıp değer bakımından arada farklılık bulunduğu için, değerce fazla olan pay veya payları alan ortak veya ortakların diğerlerine söz konusu malın dışında başka bir mal vermek ya da aradaki farkı ödemek zorunda olduğu taksim türüne kısmet-i red adı verilir. Bununla birlikte bu tür taksim satış sözleşmesine benzediğinden müşterek malın taksiminden imtina eden pay sahiplerinin taksime icbar edilmesi mümkün değildir ${ }^{81}$.

c. Müşterek Malın Bir ya da Birden Fazla Olması Açısından Taksim

Paylaştırılacak müşterek malın bir ya da birden fazla olması bakımından taksim, kısmet-i cem ve kısmet-i tefrik olmak üzere ikiye ayrılır.

Kısmet-i cem, birden fazla müşterek malın kısımlara ayrılarak paylaştırılan malların her cüzünde şayi olan hisselerin ayrılan kısımlarda toplanmasıdır. Örneğin üç kişi arasında ortak olan dokuz koyunun her birine üçer tane düşecek şekilde paylaştırılması kısmet-i cemdir. Zira ortaklardan hepsinin de her koyun üzerinde üçte bir oranında hissesi olmakla birlikte diğer koyunlardaki bu şayi hisseler taksim sonucu kendi paylarına düşen üç koyun üzerinde toplanmaktadır ${ }^{82}$. Bununla birlikte kısmet-i cem yoluyla taksim işleminin yapılabilmesi için müşterek malların parçalarının birbirine benzer olması gerekmektedir. Bu sebeple ölçülüp tartılabilen misli mallar ile değerleri arasında farklılık bulunmayan ya da önemsenmeyecek derecede az bir farklılık olan aynı türden mallar taksimin bu çeşidine konu olabilirler ${ }^{83}$.

\footnotetext{
Kâhya, s. 31.

Halebî, C. IV, s. 30; Kâhya, s. 31.

82 "Sebeb-i tahrîr-i kitâb budur ki Üveys b. Musa Şeyh meclis-i şer'de ve karındâşı Babacık? mahzarında ikrâr-ı sahîh ile ikrâr edip dedi kim işbu Dimitri b. Nikola ile biz müşấ1 müşterek koyun keçi aldık idi el-hâletü hâzihî üleşdik yüz yirmi üç re's mezkûr Dimitri payına düşdü ve yüz yirmi üç re's bizim hissemize düşdü dedikde Dimitri tasdîk ettikden sonra talebiyle deftere sebt olundu.", Yılmaz, Coşkun (editör) (2008) İstanbul Kadı Sicilleri Üsküdar Mahkemesi 1 Numaralı Sicil (H. 919-927 / M. 1513-1521), C: 1, İstanbul, İSAM, s. 223, Hüküm No: 332 [59a-2].

83 MAA, m. 1115; Ali Haydar, C. III, s. 202; Halebî, C. IV, s. 26-27; Aktan (2002), s. 498.
} 
Öte yandan kıymetleri birbirine eşit olmayan menkul ya da gayrimenkul müşterek malların taksimi, malın her cüzüne şayi olan ortaklık hisselerinin malın belli kısımlarına tayin edilmesiyle yapılır. Kısmet-i tefrik adı verilen bu tür taksim işlemi pay sahiplerinin rızası ile yapılabileceği gibi mahkeme kararıyla yapılması da mümkündür. Kısmet-i tefrik işlemi misli ya da kıyemi olması fark etmeksizin yalnızca farklı türden mallar için söz konusu olup, ortaklar arasında mutabakat sağlanmadı̆̆ müddetçe aynı cinsten olmayan mallar bir bütün olarak değerlendirilip taksim edilemez ${ }^{84}$.

\section{4. Şartları}

Taksim işleminin geçerli bir şekilde hüküm ve sonuçlarını doğurabilmesi için müşterek mal, müşterek malikler ve müşterek malı paylaştıran kişinin taşıması gerekli olan bazı şartlar vardır. Bu kapsamda müşterek mal taksim edilirken müşterek maliklerin taksim anında hazır bulunmaları $^{85}$ ya da vekillerini göndermeleri ${ }^{86}$, bazı taksim işlemlerinde pay

84 MAA, m. 1115; Ali Haydar, C. III, s. 202-203; Halebî, C. IV, s. 26-27; Aktan (2002), s. 498.

85 AK, m. 15-17; "Zeyd ve Amr, a'le’l-iştirâk bir menzilde malikler iken Zeyd, âhar diyara gitse Amr, Zeyd veya vekili hâzır değil iken menzili kadıya kısmet itdirmege kâdir olur mu? Elcevab: Olmaz.”, Çatalcalı/Demirtaş, s. 367; “... işstirâken ve şâyi an taht-ı tasarruflarımızda olup lâkin menzil ve bă̆-ı mezkûrlar käbil-i kısmet ve her birimiz hisselerimiz ile intifấ mümkün olduğuna binâen menzil-i mezkûr kısmet-i âdile ile ber-vech-i âtî taksîm olunmak murâdımdır dedikde vekîl-i merkūm el-hâc İbrahim Edhem Bey dahi cevâbında menzil-i

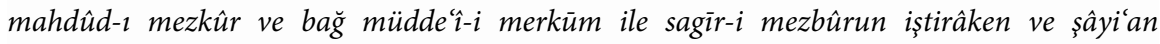
tasarruflarında olduğunu ikrâr ve menzil ve bağ-ı mezkûru kābil-i taksîm olup her biri hissesiyle intifấ mümkün olduğunu halîfetân-ı mezbûrân ve ber-vech-i muharrer taksîm olunduğu sûretde cânib-i vakfa dahi muzır olmayıp evlâ [ve] intifấ olduğunu hâzırûn-ı merkūmûn ihbâr ve taksîmini dahi câbî-i vekîl-i hâzır-ı merkūm bi'lvekâle re'y etmeğin halîfetân-ı mezbûretân ma'rifetleriyle evvelâ menzil- mezkûrun ...”, Yılmaz, Coşkun (editör) (2019) İstanbul Kadı Sicilleri 94 Anadolu Sadâreti Mahkemesi 2 Numaralı Sicil (H. 1251-1257 / M. 1835-1841), İstanbul, İstanbul Büyükşehir Belediyesi Kültür A.Ş Yayınları, s. 255-257; Hüküm No: 210 [58b-1].

$86 \mathrm{AK}, \mathrm{m} .15-17 ;$ “... leh ve aleyhimde vukû' bulmuş ve bulacak bi'l-cümle da'vâlarımı âid oldığı mahkeme-i şer 'iyye ve nizâmiye ve cezaiyede müdde 'î ve müdde 'â-aleyh ve mu'teriz ve mu 'terezun-aleyh sıfatlarıla muhâkeme ve muhâsama ve redd-i cevâba ve ikâme-i şühûd ve istimâ'-ı şühûda ve taleb-i tahlif ve istihlâfa ve kendi imzâsıyla her nev' evrâk-ı de 'âvîyi tanzîm ve takdîm ve teblĭğ ve tebellüğe ve mezkûr arâzîlerin taksime ve sâdır olacak evrâk ve i'lâmâtı ahz ve teblî̆g ve tebellüğe ve ahkâmlarinin tenfìz ve icrâsına ve'l-hâsıl husûs-ı 
sahiplerinin rızalarının aranması ve bazı taksim çeşitlerinin ise ortakların zararına yol açmaması gerekir ${ }^{87}$.

Diğer taraftan taksime konu teşkil eden müşterek malın ayn olması, taksim anında pay sahiplerinin mülkü olması ve bölünebilir ya da diğer bir deyişle taksime elverişli mallardan olması gerekmektedir ${ }^{88}$. Keza paylaştırılacak mal arazi ise sınırlarının kesin ve net olarak belirtilmesi,

mezkûrun mütevakkıf oldiğı umûrun küllîsine tarafimdan mûmâ-ileyh Safvet Efendi'yi vekâlet-i âmme-i mutlaka-i sahîha-i şer'iyye ile vekîl ve nâ'ib-i menâb nasb u ta'yîn eylediğimde ol dahi vekâlet-i mezkûreyi ber-mûceb-i muharrer kabûl ve hizmet-i lâzımesini kemâ-yenbağî edâ ve îfâya ta 'ahhüd ve iltizâm eyledi dedikde gıbbe't-tasdîki'ş-șer 'î mâ-vaka' bi't-taleb ketb olundu. (15 Cemaziyelevvel 1320/20 Ağustos 1902)”, Çetintaş, Hatice (2019) "808/1757 Numaralı Bartın Şer’iyye Sicil Defterinin Transkripsiyonu ve Değerlendirmesi” (Yüksek Lisans), Karabük Üniversitesi, Sosyal Bilimler Enstitüsü, s. 319.

Halebî, c. IV, s. 27; Kâhya, s. 33.

AK, m. 15; MAA, m. 1182-1183; "Zeyd, fevtolub annesi Hind ve li-eb karındaşı Zeyneb-i sağîreyi terkitdikde ancak bir odası olub kısmet olunduğu takdirde Hind ve Zeyneb hisseleriyle intifa' mümkün olmayub ikisi dahi mutazarrır olsalar Hind, Zeyneb'in vasîsi Amr'a 'Odayı kısmet ve hissemi ifraz itdürürüm!' dimege kâdire olur mu? El-cevab: Olmaz.”, Çatalcalı/Demirtaş, s. 368; “... her ne kadar mütevellî ve mutasarrıf ve müste'cir-i merkūmûnun rızâları yoğise de mücerred firın-ı mezkûr verâsında kâin müvekkilem mezbûrenin âhar vakıfdan tasarrufunda olan yalının selâmlık bağçesi tarafindan nısfı müvekkilem mezbûrenin hisse-i memlûkesi'çün ve nısf-ı âharı dahi vakıf için cebren ifrâz ve taksîm olunmak bi'l-vekâle matlûbumdur dedikde evvelâ firın-ı mezkûrda her birinin hissesi kısmet muhtemel olmayan şüyû' ile şâyi'a olduğundan nasîbleriyle intifâ' maksûd-ı bâkī ve mümkün olur mertebe kābil-i kısmet olmayıp tarafeyne zararı müştemil ve her vechile taksîmi vakf-ı şerîfe muzır olacağı zâhir ve mi'mârân-ı mezbûrân ve sâir bî̀-garaz ehli vakf [vukūf] ihbârlarıyla mütehakkık olduğuna binâen mütevellî ve mutasarrıf ve müste'ciri merkūmûn kısmete râzı olmadıklarını mevlânâ-yı mûmâ-ileyhim mahâllinde ketb ü tahrîr ve ma'an meb'ûs ümenâ-i şer'le bi't-terâzî dâ'îhânelerinde ma'kūd meclis-i șer'-i şerîfe gelip tarafeyn ve vâkıf-ı mûmâ-ileyh Mustafa Efendi tarafindan vekîl-i mürseli Mehmed Efendi hazır oldukları hâlde tasdîklerine mukārin alâ-vukū'ihî inhâ ve takrîr etmeleriyle bu sûretde ber-muktezâ-yı şerî‘at-i garrâ taksîmi vakfa muzır olup kābil-i kısmet dahi değil iken cebren taksîme kādir olmadiğı vekîl-i mezbûra tefhîm olunduğu ...", Yılmaz, Coşkun (editör) (2019) İstanbul Kadı Sicilleri 90 İstanbul Mahkemesi 148 Numaralı Sicil (H. 1242 / M. 1826-1827), İstanbul, İstanbul Büyükşehir Belediyesi Kültür A.Ş Yayınları, s. 161-162; Hüküm No: 105 [23a-1]. 
mirasçılara miras kalan mallardan ise taksime başlayabilmek için murisin ödenmemiş borcunun olmaması gerekir ${ }^{89}$.

$\mathrm{Bu}$ kapsamda hâkim müşterek malı paydaşlar arasında bölüştürerek şayi hisseleri bizzat belirli hale getirebileceği gibi bu görevi kâsım veya kassâm adı verilen resmi görevliye ya da bilirkişiye de tevdi edebilir. Öte yandan Osmanlı Devleti uygulamasında kassâm, miras davalarında bizzat dava mahalline giderek gerekli tahkikatı yapıp ihtilâf hakkında bir neticeye vardıktan sonra davayı hükme bağlayan ve mirasçılar arasında terekeyi taksim eden görevliye verilen isimdir ${ }^{90}$. Bu çerçevede pay sahiplerinin rızaları ile gerçekleştirilen taksim işleminde ortakların bizzat kendileri, velileri ya da görevlendirdikleri üçüncü bir kişi kâsım olabilir. Mahkeme kararı ile cebren yapılan taksim işlemlerinde ise hâkim paylaştırmayı bizzat yapabileceği gibi görevlendirdiği bir kişi aracılığıyla da yürütebilir. Bu bağlamda Osmanlı uygulamasında hâkim, müşterek malın taksimi işlemlerini bilirkişi vasıtasıyla yürütmüştür. Hâkim tarafından görevlendirilen bilirkişiler, müşterek malın ekonomik değerinin tespiti ya da fiziki olarak taksime elverişli olup olmadığ gibi hususlarda görev ifa etmişlerdir ${ }^{91}$. Keza taksime elverişli olduğu tespit

89 "Medyûnen fevtolan Zeyd'in veresesi edâ-i deyn olunmadan tereke-i Zeyd'i inkısâma kâdir olurlar mı? El-cevab: Edâ-i deyn takdim olunur.", Çatalcalı/Demirtaş, s. 365; MAA, m. 1123, 1125, 1130-1131; Ali Haydar, C. III, s. 210-215; Aktan (2002), s. 498; Kâhya, s. 33; Çelen, s. 88.

90 Öztürk, Said (2001) "Kassâm”, Türkiye Diyanet Vakfı İslam Ansiklopedisi, C: 24, s. 579; Avc1, s. 157; Ekinci (2017), s. 377.

${ }^{91}$ Kılınç, s. 174-178; “... bi'l-irsi’ş-şerî̀ verese-i mezkûresine isâbet ve intikāl edip lâkin müşterek olmağla intifâ‘ kalîl olduğundan gayri harâba müşrif olup menzil-i mezbûr verese beyninde tevzî‘ ve taksîm olunması sıgāra dahi evlâ ve enfa've kâbil-i kısmet olmağın hâlâ taraf-ı şer'den menzil-i mezbûrun üzerine varılı hâssa mimarları ve ehl-i vuküfkimesneler ma'rifetleriyle menzil-i mezbûr tashîh-i mezbûr üzere beynimizde tevzî‘ ve taksîm ve hisselerimiz ifrâz ve alâmât-ı fâsıla vaz'ıyla muhtâr kllınmak bi'l-asâle ve bi'l-vesâye ve bi'lvekâle matlûbumuzdur deyip bir kıt'a fermân-ı âlî ibrâz etmeleriyle imtisâlen-leh savb-ı şer'-i enverden Mevlânâ el-Hâc Mehmed Efendi b. Ahmed irsâl olunup ol dahi hâssa mi'mârlarından Osman Halîfe b. Süleyman ve İbrahim Halîfe b. Mustafa ile menzil-i mezbûra varıp zeyl-i vesîkada muharrerü'l-esâmi Müslimîn ile mu'âyene ve müşâhede eylediklerinde fi'l-hakīka menzil-i mezbûr ber-vech-i muharrer kābil-i kısmet olduğu âyân olmağla...", Yılmaz, Coşkun (editör) (2019) İstanbul Kadı Sicilleri 59 Rumeli Sadâreti 
edilen müşterek mallarda taksim işlemi kura ile yapılabileceği gibi belirlenen payların pay sahiplerine dağıtımı da bilirkişilerce yapılabilmiştir ${ }^{92}$. Öte yandan hâkim tarafından taksim işlemini yapmakla görevlendirilen kişinin hür, akıllı ve adil olması gerektiği gibi taksim işlemini amacına uygun şekilde gerçekleştirebilmesi için gerekli olan matematik ve benzeri bilimlerde de bilgi sahibi olması lazımdır ${ }^{93}$.

\section{Hükümleri}

İslam-Osmanlı eşya hukuku hükümleri çerçevesinde taksim işleminden sonra pay sahiplerinden her biri kendi payına müstakil olarak sahip olur ve bu hisse üzerinde dilediği gibi tasarruf edebilir. Böylece eşya üzerindeki müşterek mülkiyet sona ererek müstakil mülkiyete dönüşmüş olur. Öte yandan taksim edilen mal arazi ise, aksi kararlaştırılmadığı müddetçe arazi üzerindeki bina ve ağaçlar da taksime tâbidir. Keza paylaştırılan akara ait irtifak hakları da taksim kapsamında değerlendirilir ${ }^{4}$.

Diğer taraftan muhayyerlik sebeplerinden herhangi birini bünyesinde barındırmayan taksim işlemi adilane ve usulüne uygun olarak yapılıp yürürlüğe girdikten sonra pay sahipleri açısından bağlayıcı nitelikte bir akit

Mahkemesi 161 Numaralı Sicil (H. 1115-1116 / M. 1704), İstanbul, İstanbul Büyükşehir Belediyesi Kültür A.Ş Yayınları, s. 481-483; Hüküm No: 503 [122b-1].

92 Kılınç, s. 178; “... menzil-i mezkûr mâ-beynlerinden kısmet-i âdile ile taksîm olunmasını taleb eyleriz dediklerine binâen hâssa mi'mârlarından fahrü'l-akrân Kabil Çavuş b. Abdülmennan nâm kimesne ile ve ehl-i vuküfdan cem'-i gafir ile menzil-i mezkûrun üzerine varılıp menzil-i mezkûrun cümle binâsı kısmet-i sahîha ile takvîm olunup ve cümle arâzisi mesâha olunup cümlesi iki hisse olunup her bir hissede iki kız şerîk olmak münâsib görülmeğin menzil-i mezkûrun cânib-i cenûbîsinde olan cümle evleri, binâlar ile bahçede incir ağacına ve şeftâli ă̆acına ve bir cânibi dahi kenîfe varınca bir hisse olup ve cânib-i kıblesinde vâki' olan köşk ile önünde bahçe zikr olunan hisse müntehî olunca bir hisse olup kur'a olundukda cânib-i cenûb[un]da vâki' olan Hadice ile Rahime'nin nasîblerine düşüp ve cânib-i kıblesinde vâki olan hisse dahi Âişe ile Nesli'nin nasîblerine düşdükde vâki 'u'l-hâl bi't-taleb alâ-vukū'ihî ketb olunup yed-i tâlibe vaz' olundu ki lede'l-hâce kâşif-i mâ-cerâ ola.", Yılmaz, Coşkun (editör) (2019) İstanbul Kadı Sicilleri 44 İstanbul Mahkemesi 191 Numaralı Sicil (H. 1000-1027 / M. 1591-1617), İstanbul, İstanbul Büyükşehir Belediyesi Kültür A.Ş Yayınları, s. 99-100; Hüküm No: 56 [13b-1].

93 Halebî, C. IV, s. 26; Kâhya, s. 32-33; Çelen, s. 88.

94 MAA, m. 1162-1163, 1165; Ali Haydar, C. III, s. 249-252. 
olup, bundan rücu mümkün değildir ${ }^{95}$. Bununla birlikte kısmet-i rıza ile gerçekleştirilen paylaştırmanın uygulanması esnasında yapılan kura çekiminde kuraların çoğunun belirlenmesine karşın sahibi belirlenmeyen en az iki hisse kalmışsa ortaklardan birinin taksim işleminden rücu etmesi mümkündür. Çünkü bu tür taksimde önemli olan ortakların taksim işlemine razı olmalarıdır. Ancak kısmet-i kaza yoluyla yapılan taksim işlemlerinde hâkimin tarafları paylaşıma zorlama yetkisi olduğundan pay sahiplerinin taksimden rücu etmeleri mümkün değildir ${ }^{96}$.

Öte yandan taksim işleminden sonra taraflara düşen hisselerden herhangi birinin ayıplı olduğunun ortaya çıkması halinde ayıplı hissenin sahibi olan taraf akdin feshini talep edebilir. Keza mahkeme kararıla yapılan paylaştırma işlemlerinde gabn-i fahiş ${ }^{97}$ olması halinde taksim işleminin adil yapılmaması sebebiyle feshedilmesi mümkündür ${ }^{98}$. Nitekim Osmanlı Devleti uygulamasında bilirkişiler aracılığıyla müşterek malın taksimi esnasında gabn-i fahiş yapıldığı veya taksimin adilane bir şekilde yapılmadığı iddiaları araştırılmış ve gerektiğinde taksim işlemi adil şekilde tekrarlanmıştır ${ }^{99}$.

Müşterek malın ortaklar arasında taksim edilmesinden sonra bu malın tamamının ya da bir kısmının mala ortak olmayan başka bir kimseye ait olduğunun ortaya çıkmasına istihkak adı verilir. Malın taksimi ile meydana gelen hisselerden biri veya bir kaçının ortak olmayan bir şahsa ait olduğunun

95 AK, m. 16; MAA, m. 1127, 1157; Ali Haydar, C. III, s. 215-218, 245; "Zeyd-i müteveffânın veresesi terekeden bir bağçeyi rıâları ile kısmet-i adile ile iktisâm itdüklerinde bağçede olan havz vereseden Amr'in hissesine isâbet eylese sâir verese nâdimler olub: 'Havz beynimizde iştirâk üzere iktisâm idelim!' dimege kâdir olurlar mı? El-cevab: Olmazlar.”, Çatalcalı/Demirtaş, s. 370.

96 MAA, m. 1158; Ali Haydar, C. III, s. 245-246.

97 İki taraflı akitlerde edimler arasındaki denksizliğin aşırı olması anlamına gelen "gabn-i fahiş” hakkında ayrıntılı bilgi için bakınız: Bardakoğlu, Ali (1996) “Gabn”, Türkiye Diyanet Vakfı İslam Ansiklopedisi, C: 13, s. 268-273.

98 MAA, m. 1160; Ali Haydar, C. III, s. 246-247; “Zeyd ve Amr a’le’l-iştirâk malik oldukları kâbil-i kısmet olan emlâki iktisâm itdüklerinden sonra Zeyd, istîfai hakka ikrar itmeden: 'Hissemde gabn-i fâhiş olmuşdur!' deyu da'vâ ve gabn-i fâhişi isbât idicek ol emlâki kısmet-i âdile ile kısmet itdürmege kâdir olur mu? El-cevab: Olur.”, Çatalcalı/Demirtaş, s. 371.

Kılınç, s. 182. 
ortaya çıkması durumunda yapılan taksim bozulmayıp, hissesinin başkasina ait olduğu ortaya çıkan ortak veya ortakların zararı giderilir ${ }^{100}$. Buna karşın taksimden sonra paylaştırılan malın tamamının bir başkasına ait olduğunun ortaya çıkması taksim işleminin feshine yol açar. Keza terekenin mirasçılar arasında bölüştürülmesinden sonra murisin dağıtılan terekeye denk bir borcu olduğunun ortaya çıkması da taksimin feshini gerektirir ${ }^{101}$.

Diğer taraftan ortakların tamamının muvafakati ile kısmet-i rıza ya da kısmet-i kaza yoluyla yapılan taksim işleminin ikâle ${ }^{102}$ yoluyla feshedilmesi de mümkündür. Böylece pay sahipleri söz konusu malı taksimden önce olduğu gibi aralarında müşterek olarak kullanabilirler ${ }^{103}$.

\section{B. MÜŞTEREK MENFAATLERIN TAKSIMII (MUHÂYEE)}

$\mathrm{Bu}$ başlık altında muhâyeenin tanımı yapılarak hukuki niteliği, hukuki dayanağı, çeşitleri, şartları ve sonuçları üzerinde durulacaktır

\section{Tanımı ve Hukuki Niteliği}

Sözlük anlamı olarak "birden fazla kişinin belirli bir durum üzerinde uzlaşmaları" ya da "taraflardan her birinin vaat ettiğini hazır ve elverişli hale getirmesi” demek olan muhâyee İslam hukuku terimi olarak ise zaman sıralaması ya da mekân belirlenmesi suretiyle müşterek maliklerin söz konusu maldan yararlanma usulü hakkında anlaşmaları anlamına gelmektedir. Diğer bir deyişle birden fazla kişinin birlikte malik olduğu mal ya da malların

100 "Zeyd-i müteveffânın veresesi tereke-i Zeyd-i iktisâm itdüklerinde vereseden Amr'ın hissesine şu kadar eşya isâbet idüb kabzitdikden sonra Bekir ol eşyaya müstahık çıkub ba'de’l-isbat ve'l-hukm eşyayı Amr'dan alsa Amr hissesiyle diğer vereseye terekeden makbuzlarından mürâcaata kâdir olur mu? El-cevab: Our.", Çatalcalı/Demirtaş, s. 372.

101 MAA, m. 1161; Ali Haydar, C. III, s. 247-249; Halebî, C. IV, s. 31.

102 Bağlayıcı ve feshi kabil bir akdi bozmayı konu edinen ikâle akdi hakkında ayrıntılı bilgi için bakınız: Aybakan, Bilal (2000) “İkâle”, Türkiye Diyanet Vakfı İslam Ansiklopedisi, C: 22, s. 14-16.

103 MAA, m. 1179; Ali Haydar, C. III, s. 246. 
müşterek mülkiyet devam ettiği sürece hissedarlar arasında nasıl kullanılacağını düzenleyen sözleşmeye muhâyee adı verilmektedir ${ }^{104}$.

Niteliği bakımından muhâyeenin bir akit olduğu hususunda İslam hukukçuları arasında görüş birliği olmakla birlikte bu akdin hükümleri açısından ne tür bir akit olduğu konusu tartışmalıdır. Bu kapsamda bazı İslam hukukçularına göre pay sahipleri sahibi oldukları şayi hisselerden elde edecekleri menfaati diğer paydaşlarla değiştirdiklerinden dolayı muhâyee bir tür kira akdi niteliğindedir. Nitekim kira sözleşmelerinde kira bedelinin nakit para olması zorunlu değildir. Keza muhâyee akdini aynların değişimini ifade etmesi açısından trampaya benzetmek mümkün olmamakla birlikte tarafların hem kiralayan hem de kiracı durumunda olmaları sebebiyle trampaya benzediği söylenebilir. Nitekim klasik İslam hukuku eserlerinde yer yer başka akit tipleriyle ilişki ve benzerliklerine temas edilmekle birlikte genellikle ivazlı olduğu ve bu sebeple icâre hükümlerinin uygulanması gerektiğinin belirtilmesi muhâyeenin kira sözleşmesine benzediği yaklaşımını desteklemektedir. Buna karşın bazı İslam hukukçularının da belirttiği üzere bu akit bütün hükümleri bakımından kira sözleşmesi gibi değildir. Zaman itibariyle muhâyeenin mübadele yönü, mekân itibariyle muhâyeenin ise ifraz yönü dikkate alınarak birincisinde sürenin belirli olması şart koşulurken ikincisinde süre tayini gerekli görülmemiştir. Ancak süre tayini hükmünden bağımsız olarak incelendiğinde her iki türün bir yönüyle ifraz, diğer yönüyle mübadele olduğu söylenebilir ${ }^{105}$.

\section{Hukuki Dayanağı}

Müşterek mülkiyete konu teşkil eden malların taksiminde asıl olan ortakların rızası ya da mahkeme kararıyla malın aynen paylaştırılmasıdır. Ancak taksime elverişli olmayan ya da paylaştırılması halinde önemli ölçüde değer kaybına uğrayan mallar gibi bazı müşterek malların ise taksimden

104 Dönmez, s. 509-510; Bilmen, C. VII, s. 155; Halebî, C. IV, s. 32; Ali Haydar, C. III, s. 259; Karaman, C. III, s. 53; Türcan, Talip (2000) "İslam Hukukundaki Muhâyee ve Türk Hukukundaki Devre Mülk Kurumları Arasında Bir Mukayese”, Süleyman Demirel Üniversitesi İlahiyat Fakültesi Dergisi, S: 7, s. 83-84.

105 MAA, m. 1178-1179; Ali Haydar, C. III, s. 264-265; Dönmez, s. 510-511; Kâhya, s. 54-57;

Türcan, s. 93. 
ziyade devamı daha yararlı olabilir. Bu kapsamda müşterek mülkiyetin aynen devam etmesine karşın müşterek maldan yararlanma hakkının paylaştırılması anlamına gelen muhâyeenin meşruluğu İslam hukukunun asli kaynakları olan Kur'an-1 Kerim ve Hz. Peygamber'in sünnetine dayanmaktadır. Nitekim Kur'an'da yer alan ve Salih Peygamber ile kavmi arasındaki su kullanımında meydana gelen ihtilafın çözümünü haber veren ayetlere ${ }^{106}$ göre suyun Salih Peygamber'in devesi Mucize ile kavmi arasında nöbetleşe kullanılması emredilmiştir. İslam hukukçularına göre suyun kullanım hakkının paylaştırılmasına ilişkin olan bu uygulama, İslamiyet öncesi toplumlara ait olmakla birlikte söz konusu ayetin nesh edildiğine dair herhangi bir delil olmadığından, menfaatlerin taksimi işlemi (muhâyee) İslam-Osmanlı eşya hukukuna göre de mümkündür. Keza Bedir Savaşında Hz. Peygamber'in develerden her birini üç kişi arasında paylaştırması ve onların da dönüşümlü olarak bu develere binmeleri muhâyeenin sünnetteki delili olarak gösterilebilir $^{107}$.

Öte yandan Mecelle-i Ahkâm-1 Adliyye'nin 1174-1191. maddeleri muhâyeenin Osmanlı Devleti uygulamasındaki yasal dayanağı olarak gösterilebilir.

\section{3. Çeşitleri}

İslam-Osmanlı eşya hukuku hükümleri çerçevesinde muhâyee akdi çeşitli açılardan farklı tasniflere tabi tutulmuştur. Bu kapsamda muhâyee; zamana ya da mekâna bağlılığı açısından zamanen muhâyee ve mekânen muhâyee olmak üzere ikiye ayrılırken, tarafların iradesine bağlı olup olmamasına göre rızaen muhâyee ve kazaen muhâyee olmak üzere ikiye ayrılmaktadır.

Müşterek maliklerden her birinin eşit veya payıyla orantılı bir süre için aralarında ortak olan malın tamamından sırayla istifade etmelerine zamanen muhâyee adı verilir. Örneğin iki kişinin müşterek malik oldukları arsayı bir yıl

\footnotetext{
106 "Salih: İște (mucize) bu dişi devedir; onun bir su içme hakkı vardır, belli bir günün içme hakkı da sizindir, dedi.", Şuarâ, 26/155; "Onlara, suyun aralarında paylaştırıldığını haber ver. Her biri kendi içme sırasında gelsin.", Kamer, 54/28.
}

107 Dönmez, s. 510; Sağlam, s. 372; Çelen, s. 91-92; Kâhya, s. 43-46. 
birinin diğer yıl bir diğerinin kullanması ya da ortakların sahibi oldukları evi sırayla kullanmaları zamanen muhâyee olarak kabul edilir ${ }^{108}$. Müşterek mülkiyetin devam etmesi kaydıyla ortaklardan her birinin payıla orantılı olacak şekilde müşterek malın bir kısmından istifade etmesine ise mekânen muhâyee denilir. İki kişinin müşterek maliki oldukları dört odalı bir evin odalarını ikişerli paylaşarak her birini ortaklardan birinin kullanması mekânen muhâyee akdine örnek olarak verilebilir ${ }^{109}$.

108 MAA, m. 1176-1178; Ali Haydar, C. III, s. 262-2654; Halebî, C. IV, s. 32-33; Dönmez, s. 510; Karaman, C. III, s. 53; Türcan, s. 89-90; "Mahmiye-i İstanbul'da Çelebioğlu Mahallesi sükkânından Mehmed Çelebi b. Ahmed nâm kimesne meclis-i şer'-i şerîf-i enverde li-ebeveyn kız karındaşı Sâliha'nın zevci ve tarafindan husûs-ı âti'l-beyâna vekîl olduğu nehc-i șer'î ve tarîk-i merî̀ üzere şer'an sâbit olan Mehmed Bey b. Abdurrahman nâm kimesne muvâcehesinde takrîr-i kelâm ve bast-ı merâm edip ashâb-ı hayrâtdan merhûm Koca Mustafa Paşa Vakfi müstagallâtından olup mahalle-i mezkûrede vâki' ma'lûmül-hudûd hâriciye ve dâhiliyede büyût-ı adîdeyi müstemil menzilin üç hisseden bir hissesi benim ve iki hissesi kız karındaşım müvekkile-i mezkûrenin taht-ı tasarrufumuzda olup menzil-i mezkûr vakıf olmağla mütevellî-i vakf-ı mezbûr taksîme izin vermediğinden gayrı hisselerimiz mikdârı taksîme benim dahi rızâm olmayıp vemuhâye'e-i mekâniye mümkün olmamağla muhâye'e-i zamâniye ile her birimiz hisse mikdârı sâkin olmak lâzım gelmeğin her bir senede dört ay ben ve sekiz ay karındaşım müvekkile-i mezkûre sâkine olmak üzere vekîl-i mezkûr ile kavl ü ittifâk edip ...”, Yılmaz, Coşkun (editör) (2019) İstanbul Kadı Sicilleri 60 Bab Mahkemesi 92 Numaralı Sicil (H. 1120-1121 / M. 1709), İstanbul, İstanbul Büyükşehir Belediyesi Kültür A.Ş Yayınları, s. 500-501, Hüküm No: 563 [82b-1]. MAA, m. 1176, 1179; Ali Haydar, C. III, s. 262-263, 265; Halebî, C. IV, s. 32-33; Karaman, C. III, s. 53; Dönmez, s. 510; Türcan, s. 90; “... menzil-i mezbûr kābil-i kısmet olmağla tevliyetim hasebiyle kız karındaşım mezbûre Havva ile beynimizde muhâyee bi'l-mekân vechi üzere taksîm olunmak matlûbumdur dedikde gibbe't-tasdîkı'ş-şer'î mi'mârân-ı mezbûrân menzil-i mezbûru mesâha eylediklerinde tûlen ve arzen bi-hesâbı terbî̀̂ beş yüz kırk iki zirâ' binâlı arsa ve üç bin altı yüz yetmiş sekiz zirâ‘ arsa-i hâliyeden mezbûrân el-Hâc Hürrem Çelebi ve Havva'dan herbirine ikişer yüz yetmiş birer zirâ' binâlı arsa ve bin sekiz yüz otuz dokuzar zirâ' arsa-i hâliye isâbet etdiği zâhir ve müte'ayyen olmağın dâhiliyede vâki' tahtânî üç bâb oda ve sofa ve hamam ve câmekân odası ve sofanın köşesinde vâki' direkden cunba üçüncü parmaklıkdan doğru kal'a duvarı ve bende vaz' olunan alâmete müntehî oluncaya değin să̆ cânibde vâkı'a hadîka mezbûr el-Hâc Hürrem Çelebi'ye hisse ta'yîn olunup ve hâriciye-i menzil-i mezbûr ma'a arsa-i hâliye ve dâhiliyede vâki' matbah ve köşk ve orta kapı ve sol tarafda vâki'a bâkī hadîka mezbûre Havva'ya hisse ta'yîn ve tahsîs olundukda herbiri muhâyee bi'l-mekân vechi üzere kabz ve kabûl etmeğin ...", Yılmaz, Coşkun (editör) (2019) İstanbul Kadı Sicilleri 57 İstanbul Mahkemesi 22 Numaralı Sicil (H. 1107-1108 / M. 
Müşterek maliklerin ortak oldukları maldan nasıl yararlanacaklarını serbest iradeleriyle belirlemelerine rızaen muhâyee adı verilip, bu tür muhâyee akdinde taraflar müşterek malın kullanım şeklini özgür iradeleriyle diledikleri gibi belirleyebilirler. Nitekim bu kullanım şekli müşterek malın zamanen veya mekânen kullanılması şeklinde olabilir ${ }^{110}$. Bununla birlikte muhâyee akdinin müşterek maliklerden birinin talebi üzerine mahkeme kararıla (kazaen) kurulması da mümkündür. $\mathrm{Bu}$ durumda kısmet-i kazada olduğu gibi taraflardan biri muhâyee talep ettiği halde diğeri bundan imtina etmektedir. Muhâyee talep eden tarafın mahkemeye müracaat etmesi sonucu hâkim imtina eden tarafı muhâyeeye zorlamaktadır ${ }^{111}$.

\section{4. Şartları}

Muhâyee akdinin tarafları müşterek malikler olup bunların İslam hukuku hükümleri çerçevesinde ivazlı akitlerde aranan ehliyete ilişkin şartları taşımaları gerekmektedir. Buna göre gayri mümeyyiz küçük veya akıl hastası gibi eda ehliyetine hiç sahip olmayan kişilerin yapmış oldukları muhâyee akdinin geçerliliği yoktur. Bununla birlikte Hanefi ve Maliki mezheplerine mensup hukukçulara göre ayırtım gücüne sahip küçük veya sefih gibi eksik eda ehliyetine sahip kişilerin yapmış oldukları muhâyee akitleri ancak veli ya da vasilerinin onayıly geçerli olur. Şafii ve Hanbeli mezheplerinde ise eksik eda ehliyetliler tarafından yapılan hukuki işlemler geçerli sayılmadığı için bu kişilerin muhâyee akdi yapabilmeleri için bülûğa ulaşmaları şarttır ${ }^{112}$.

Muhâyee akdinde tarafların müşterek olarak menfaatine sahip oldukları mal ya da mallardan zaman veya mekân açısından yapılan paylaşıma göre yararlanmaları söz konusudur. Dolayısıyla muhâyee işlemi müşterek malın

1695-1697), İstanbul, İstanbul Büyükşehir Belediyesi Kültür A.Ş Yayınları, s. 119-120, Hüküm No: 44 [15b-1].

110 Dönmez, s. 510; Kâhya, s. 72; Türcan, s. 91.

111 MAA, m. 1181-1183; Ali Haydar, C. III, s. 265-266; Elmalılı, C. III, s. 450; Dönmez, s. 510; Kâhya, s. 74 Türcan, s. 91-92; "Hind ile Zeyneb'in a'le'l-iştirâk mâlike oldukları oda kâbil-i kısmet olmamağla Hind, Zeyneb'e: 'Odada muhâyeeten sâkine olalım' didikde Zeyneb râziye olmayub 'Ancak ben sâkin olurum!' dimege kâdire olur mu? El-cevab: Olmaz.", Çatalcalı/Demirtaş, s. 368.

112 Dönmez, s. 510; Kâhya, s. 48-49. 
aynen devam etmesiyle birlikte, kendisinden yararlanılması mümkün olan ortak mallarda mümkün olur. Buna göre muhâyee ölçü, tartı veya tane ile satılan misli mallarda değil ancak kıyemi mallarda söz konusu olabilir. Çünkü misli mallar aynları devam ettiği müddetçe kendilerinden yararlanılması mümkün olmayan mallar olduğu halde kıyemi mallar ise aynları devam etmekle birlikte kendilerinden istifade edilmesi mümkün olan mallardır ${ }^{113}$.

\section{Hükümleri}

İslam eşya hukuku hükümleri çerçevesinde muhâyee akdi sonucunda taraflar; mekânen muhâyee yapmışlarsa müşterek malın kendi hisselerine düşen kısmına, zamanen muhâyee yapmışlarsa kendi sıraları geldiğinde müşterek malın tamamını kullanma hakkına sahip olurlar. Buna karşın mezhepler arasında farklı görüş bulunmakla birlikte Osmanlı Devleti'nin de resmi mezhebi olan Hanefi mezhebine mensup hukukçular muhâyee akdinin bağlayıcılığı hususunda akdin rızaen veya kazaen kurulmasına göre farklı görüşler ortaya koymuşlardır. Bu kapsamda muhâyee akdi pay sahiplerinin rızaları ile meydana gelmişse, ortaklardan birinin tek taraflı olarak muhâyeeyi feshetme yetkisi vardır ${ }^{114}$. Ancak pay sahiplerinden birisi müşterek malı kullanma hakkını bir başkasına kiraya vermişse kira sözleşmesi sona erene kadar ortaklar muhâyee akdini feshedemezler ${ }^{115}$.

113 MAA, m. 1175; Ali Haydar, C. III, s. 262; Halebî, C. IV, s. 32; Elmalılı, C. III, s. 443-444; Türcan, s. 87.

114 “... biz sene-i mezbûre Recebi'l-ferdi gurresinden i'tibâren evvelen ben müstakkıllen bir sene ve sâniyen mezbûre Âişe Hatun kezâlik müstakilleten bir sene zabtetmek üzre mütevelliye-i hâzıra-ı mezbûrenin izniyle kur'a-i şer'iye olunarak bâ-ilâm akd-i muhâyee etmişdik elhâletü hâzihî biz beynimizde bi't-terâzî fesh-i akd-i muhâyee-birle ben menzil-i mahdûd-ı mezkûrda olan nısf hisse-i şâyi amı hüsn-i rızâ ve tayyib-i hâtırım ve ferâğ-ı mu'teber-i kat t̂̀ ile sekiz yüz guruş bedel-i makbûz-ı müstehlek mukābelesinde mezbûre Âișe Hatun'a ferâğ ve tefvîz ve teslìm eylediğimde ol dahi tefevvüz ve kabûl ve mütevelliye-i hâzıra-i mezbûre dahi tasarrufuna izin verip ol vechile menzil-i mahdûd-ı mezkûrun mecmû'u üzre Âişe Hatun'un dâhil-i havza-i tasarrufu ve hakk-ı müfevvazı olup benim kat'a alâka ve medhalim kalmamağla ...", Yılmaz (editör), İstanbul Kadı Sicilleri 90, s. 208-209, Hüküm No: 146 [31b-2].

115 MAA, m. 1188, 1190; Ali Haydar, C. III, s. 269-270; Halebî, C. IV, s. 34; Bilmen, C. VII, s. 159; Türcan, s. 93; Kâhya, s. 113 vd. 
Öte yandan müşterek maliklerden birinin istemesine rağmen diğerinin imtina etmesi sonucu mahkeme kararıla meydana gelen muhâyee akdini ise ortaklardan herhangi birisi yalnızca malın aynen taksimi ya da kendi hissesini satmak istemesi gibi makul bir gerekçeye dayanmak suretiyle feshedebilir. Aksi takdirde kazaen meydana gelen muhâyee akitlerinde ortakların tek taraflı olarak fesih yetkileri yoktur. Buna karşın ortaklar bir araya gelmek suretiyle kendi aralarında uzlaşarak mahkeme kararının aksine muhâyee akdini feshedip ortaklığı sürdürebilirler ${ }^{116}$.

Diğer taraftan müşterek maliklerden birisinin ya da her ikisinin ölümü halinde muhâyee akdi sona ermediği gibi muhâyee akdinden doğan tüm haklar ve borçlar mirasçılara intikal eder. Çünkü ortakların ölümü ile muhâyee akdinin sona ereceğinin kabul edilmesi halinde mirasçıların tekrar muhâyee talebinde bulunmaları gerekeceğinden bunda hukuki yarar olmadığı kabul edilir ${ }^{117}$.

\section{SONUÇ}

Tarih boyunca tüm toplumlarda eşya ve mülkiyete ilişkin hukuki esaslar benimsendiği gibi İslam hukuku da bu konuya dair orijinal esaslar getirmiştir. İslam hukuku ile eşyaya ve mülkiyete ilişkin olarak getirilen hükümler Osmanlı hukukunda da hemen hemen aynı şekilde kabul edilip uygulanmıştır ${ }^{118}$.

Bu kapsamda müşterek mülkiyet; satın alma, hibe, vasiyeti kabul veya miras gibi mülkiyeti kazanma yollarından biriyle ya da birden fazla malın ayrılması mümkün olmayacak bir biçimde birbirlerine karışarak birleşmesi suretiyle en az iki kimsenin bir mal üzerinde birlikte malik olmalarıdır. Dolayısıyla müstakil mülkiyete konu olan bir eşyaya yalnızca bir kişi sahip olduğu halde müşterek mülkiyete konu teşkil eden bir eşyanın birden çok maliki bulunmaktadır. Bununla birlikte müşterek olarak bir mala sahip olan

\footnotetext{
116 MAA, m. 1189; Ali Haydar, C. III, s. 270; Elmalılı, C. III, s. 454; Bilmen, C. VII, s. 159; Kâhya, s. 113 vd.

117 MAA, m. 1191; Ali Haydar, C. III, s. 270; Kâhya, s. 143-144.

118 Cin, s. 9.
} 
pay sahipleri o malın belli bir bölümü üzerinde hisseleri oranında malik olmayıp, pay sahiplerinin mülkiyet hakkı malın tamamı üzerinde kendi hissesi oranındadır. Bu nedenle bir malın müstakil mülkiyetine sahip olan şahıs o mal üzerinde dilediği gibi tasarrufta bulunabileceği halde, müştereken bir mala sahip olan ortakların o mal üzerinde tasarruf yetkileri bazı kısıtlamalara tabidir. Bu doğrultuda müşterek mal üzerinde pay sahiplerinden her biri kendi paylarına ilişkin olarak bazı tasarrufları tek başlarına yapabildikleri halde bir kısım tasarrufları ise sınırlandırılmıştır. Keza İslam-Osmanlı hukukunda müşterek malın yok olması, istimlâk edilmesi, cebri satışı ya da malın kendisinin veya menfaatlerinin taksim edilmesi suretiyle müşterek mülkiyet sona erdirilebilir.

İslam-Osmanlı eşya hukukunda müşterek mülkiyeti sona erdiren sebeplerden taksim bir eşyanın ayn adı verilen maddi yapısının taksimi ya da malın maddi yapısı aynen kalmakla birlikte bu maldan elde edilen menfaatlerin taksimi olmak üzere iki şekilde yapılmaktadır. Ancak klasik İslam hukuku eserlerinde "taksim” kavramı ile esasen müşterek malın maddi yapısının paylaşılması kastedilmekte olup, menfaatlerin taksimi ise "muhâyee" kavramı ile ifade edilmiştir.

Öte yandan neticesi itibariyle müşterek mal üzerinde şayi olan hisselerin ayrılmasına yol açan taksim işlemi bu yönüyle bir ifraz niteliğinde olmakla birlikte söz konusu işlem sonucunda her bir ortak kendi payına düşen hisseden diğer ortakların vazgeçmelerine karşılık onlara düşen hisselerdeki mülkiyet hakkından feragat ettiğinden aynı zamanda mübadele özelliği de taşımaktadır.

Diğer taraftan müşterek malın taksimi; pay sahiplerinin iradeleri açısından kısmet-i rıza ve kısmet-i kaza şeklinde ikiye; müşterek malın paylaştırılması sonucunda ortaya çıkan payların eşitlenmesine ihtiyaç duyulup duyulmamasına göre kısmet-i ecza, kısmet-i tadil ve kısmet-i red olmak üzere üçe; paylaştırılacak malın bir ya da birden fazla olması açısından ise kısmet-i cem ve kısmet-i tefrik olmak üzere ikiye ayrılmaktadır.

Ayrıca müşterek malın taksim edilebilmesi için ayn olması, bölünebilir olması ve taksim işlemi sırasında pay sahiplerinin mülkiyetinde bulunması gerekir. Keza müşterek maliklerin taksim anında hazır bulunmaları ya da 
vekillerini göndermeleri, bazı taksim işlemlerinde pay sahiplerinin rızalarının aranması ya da bazı taksim türlerinde ortakların zarara uğramaması taksimin şartlarındandır.

Usulüne uygun ve adil olarak yapılan taksim işlemi taraflar açısından bağlayıcı nitelikte olup, bundan rücu mümkün değildir. Ancak ortakların rızası ile gerçekleştirilen taksimin uygulanması esnasında dağıtılmayan en az iki hisse kalmışsa ortaklardan birinin taksimden rücu etmesi mümkündür. Çünkü bu tür taksimde önemli olan pay sahiplerinin taksim işlemine razı olmalarıdır. Bununla birlikte mahkeme kararıyla gerçekleştirilen taksim işlemlerinde hâkimin tarafları paylaştırmaya zorlama yetkisi olduğundan pay sahiplerinin taksimden rücu etmeleri mümkün değildir.

Müşterek mülkiyete konu teşkil eden malların taksiminde asıl olan ortakların rızası ya da mahkeme kararıyla malın aynen paylaştırılmasıdır. Ancak taksime elverişli olmayan ya da paylaştırılması halinde önemli ölçüde değer kaybına uğrama ihtimali olan mallar gibi bazı müşterek malların devamı, taksim edilmesinden daha yararlı olabilir. Bu durumda müşterek mülkiyetin aynen devam etmesine karşın müşterek maldan yararlanma hakkının paylaştırılmasına muhâyee adı verilmektedir.

Bu kapsamda İslam-Osmanlı hukukunda müşterek malın taksimi hususunu incelemeye çalıştığımız bu çalışma, elbette dar kapsamlı ve bazı eksiklikleri olabilecek bir çalışma olup, eşya hukukunun önemli konu başlıklarından olan müşterek mülkiyet ve taksimi hususu hukuk tarihi açısından çok daha geniş kapsamlı ve ayrıntılı çalışmalara konu olabilecek niteliktedir. 


\section{KAYNAKÇA}

Akgündüz, Ahmet (1996) İslam Hukukunda ve Osmanlı Tatbikatında Vakıf Müessesesi, 2. Baskı, İstanbul, Osmanlı Araştırmaları Vakfı.

Aktan, Hamza (2001) "İstimlâk", Türkiye Diyanet Vakfı İslam Ansiklopedisi, C: 23, s. 364-366.

Aktan, Hamza (2002) "Kısmet", Türkiye Diyanet Vakfı İslam Ansiklopedisi, C: 25, s. 497-498.

Aktan, Hamza (2005) “Miras”, Türkiye Diyanet Vakfı İslam Ansiklopedisi, C: 30, s. 143-145.

Ali Haydar Efendi (2014) Dürerü'l-Hukkâm Şerhu Mecelleti'l-Ahkâm, C. IIV, (Çeviren: Gündoğdu, Raşit/Erdem, Osman) İstanbul, Gül Neşriyat.

Apaydın, H. Yunus (2001) "Karz", Türkiye Diyanet Vakfı İslam Ansiklopedisi, C: 24, s. 520-525.

Arı, Abdüsselam (2012) "Vasiyet", Türkiye Diyanet Vakfı İslam Ansiklopedisi, C: 42, s. 552-554.

Armağan, Servet (2015) İslam Hukukunda Temel Hak ve Hürriyetler, 8. Baskı, Ankara, Diyanet İşleri Başkanlığı Yayınları.

Atar, Fahrettin (1990) İslam İcra ve İflas Hukuku, 1. Bask1, İstanbul, Marmara Üniversitesi İlahiyat Fakültesi Vakfı Yayınları.

Avcı, Mustafa (2018) Türk Hukuk Tarihi, 7. Bası, Konya, Atlas Akademi.

Aybakan, Bilal (2000) "İkâle", Türkiye Diyanet Vakfı İslam Ansiklopedisi, C: 22, s. 14-16.

Aydın, Mehmet Akif (2014) Türk Hukuk Tarihi, 12. Baskı, İstanbul, Beta Basım Yayım.

Aydın, Münevver (2019) "185 Numaralı Denizli Şer'iyye Sicil Defterinin Transkripsiyonu ve Değerlendirmesi (1875-1883)" (Yüksek Lisans), Afyon Kocatepe Üniversitesi, Sosyal Bilimler Enstitüsü.

Bardakoğlu, Ali (1992) “ Bey' ”, Türkiye Diyanet Vakfı İslam Ansiklopedisi, C: 6, s. 13-19.

Bardakoğlu, Ali (1996) “Gabn”, Türkiye Diyanet Vakfı İslam Ansiklopedisi, C: 13 , s. 268-273. 
Bardakoğlu, Ali (1998) "Hibe", Türkiye Diyanet Vakfı İslam Ansiklopedisi, C: 17, s. 421-426.

Bardakoğlu, Ali (1998) “Hidâne”, Türkiye Diyanet Vakfı İslam Ansiklopedisi, C: 17 , s. 467-471.

Bilmen, Ömer Nasuhi (t.y.) Hukuk-1 İslamiyye ve Istılahat-1 Frkhiyye Kâmusu, C. IV-VII, İstanbul.

Cin, Halil (1992) Osmanlı Toprak Düzeni ve Bu Düzenin Bozulması, 3. Baskı, Konya, Selçuk Üniversitesi Basımevi.

Cin, Halil/Akgündüz, Ahmed (2011) Türk Hukuk Tarihi, İstanbul, Osmanlı Araştırmaları Vakfı.

Cin, Halil/Akyılmaz, Gül (2013) Türk Hukuk Tarihi, 5. Baskı, Konya, Sayram Yayınları.

Çalış, Halit (2007) "Rakabe”, Türkiye Diyanet Vakfı İslam Ansiklopedisi, C: 34, s. 427-428.

Çatalcalı Ali Efendi/Demirtaş, H. Necati (2014) Açılamalı Osmanlı Fetvaları: Fetâvâ-yı Ali Efendi, cild-i sâni, 1. Baskı, İstanbul, Kubbealtı,

Çelen, Cevdet (2010) “İslam Hukukunda Müşterek Mülkiyet” (Yüksek Lisans), Marmara Üniversitesi, Sosyal Bilimler Enstitüsü.

Çetintaş, Hatice (2019) “808/1757 Numaralı Bartın Şer’iyye Sicil Defterinin Transkripsiyonu ve Değerlendirmesi” (Yüksek Lisans), Karabük Üniversitesi, Sosyal Bilimler Enstitüsü.

Dönmez, İbrahim Kâfi (2010) "Şüfa", Türkiye Diyanet Vakfı İslam Ansiklopedisi, C: 39, s. 248-252.

Duman, Ali (2008) "Sadaka", Türkiye Diyanet Vakfi İslam Ansiklopedisi, C: 35, s. 383-384.

Ekinci, Ekrem Buğra (2016) İslam Hukuku: Umumi ve Hususi Hükümler, 2. Basım, İstanbul, Arı Sanat Yayınevi.

Ekinci, Ekrem Buğra (2017) Osmanlı Hukuku: Adalet ve Mülk, 5. Basım, İstanbul, Arı Sanat Yayınevi.

Elmalılı Muhammed Hamdi Yazır (1997) Alfabetik İslam Hukuku ve Fıkıh Istılahları Kamusu, C. III, (Hazırlayan: Sıtkı Gülle), İstanbul, Ensar Neşriyat. 
Erkal, Mehmet (1996) “Ganimet", Türkiye Diyanet Vakfı İslam Ansiklopedisi, C: 13, s. 351-354.

Fendoğlu, Hasan Tahsin (1994) Hukuk Tarihimizde Temel Haklar, Konya, Mimoza.

Gözübenli, Beşir (1991) “Âriyet”, Türkiye Diyanet Vakfı İslam Ansiklopedisi, C: 3, s. 379-380.

Gözübenli, Beşir (2002) "Kıyemî", Türkiye Diyanet Vakfı İslam Ansiklopedisi, C: 25, s. 540-541.

Hacak, Hasan (2005a) "İslam Hukuk Düşüncesinde Özel Mülkiyet Anlayışı”, Marmara Üniversitesi İlahiyat Fakültesi Dergisi, C: 29, S: 2, s. 99-120.

Hacak, Hasan (2004) “Menfaat”, Türkiye Diyanet Vakfı İslam Ansiklopedisi, C: 29, s. 131-134.

Hacak, Hasan (2001b) "Mislî”, Türkiye Diyanet Vakfı İslam Ansiklopedisi, C: 30, s. $187-188$.

Hacak, Hasan (2006a) "Mülkiyet", Türkiye Diyanet Vakfı İslam Ansiklopedisi, C: 31, s. 543-548.

Hacak, Hasan (2006b) “ Müşầ” ”, Türkiye Diyanet Vakfi İslam Ansiklopedisi, C: 32, s. 151-152.

Hacak, Hasan/Çalış, Halit (2007) "Rehin”, Türkiye Diyanet Vakfı İslam Ansiklopedisi, C: 34, s. 538-542.

İbrahim Halebî (t.y.) Mevkûfât Mültekâ Tercümesi, c. IV, (Şerheden: Mehmed Mevkûfâti, Sadeleştiren: Ahmed Davudoğlu), İstanbul, Sağlam Kitabevi.

Kahveci, Nuri (2015) Mukayeseli İslam Borçlar Hukuku, 1. Baskı, İstanbul, Hikmet Yayınevi.

Kâhya, Özlem (2009) “İslam Hukukunda Muhâye'e” (Yüksek Lisans), Marmara Üniversitesi, Sosyal Bilimler Enstitüsü.

Karaman, Hayrettin (2012) Mukayeseli İslam Hukuku, c. III, İstanbul, İz Yayıncilık.

Karaman, Hayrettin/Özek, Ali/Dönmez, İbrahim Kâfi/Çağrıcı, Mustafa/Gümüş, Sadrettin/Turgut, Ali (2014), Kur’an-1 Kerim ve Açıklamalı Meâli, 27. Baskı, Ankara, Türkiye Diyanet Vakfı Yayınları. 
Kılınç, Ahmet (2019) Osmanlı Yargılama Hukukunda Bilirkişilik, 1. Baskı, Ankara, Adalet Yayınevi.

Kıylık, Mustafa Harun (2016) "Aile İçi Eğitim Açısından İslam Hukukunda Hidane", Yurt, Mehmet Emin/Bayrktutan Osman (Editörler), Iğdır Üniversitesi İlahiyat Fakültesi Uluslararası Aile İçi Eğitim Çalıştayı, Iğdır, s. 143-178.

Özdemir, Recep (2019) "İslam Hukukuna Göre Mülkiyet ve Mülkiyetin Temellendirilmesi”, Adıyaman Üniversitesi Sosyal Bilimler Enstitüsü Dergisi, Y: 11, S: 31, s. 259-291.

Öztürk, Said (2001) "Kassâm”, Türkiye Diyanet Vakfı İslam Ansiklopedisi, C: 24, s. 579-582.

Sağlam, Hadi (2012) “İslam Fıkıh Doktrininde Müşterek Mülkiyetin Taksiminde Muhdesatın Durumu (İştirak ve Müşterek Araziler Örneği)", Cumhuriyet Üniversitesi İlahiyat Fakültesi Dergisi, C: 16, S: 2, s. 365-415.

Şener, Mehmet (1989) "İslam Hukukunda Karz-1 Hasen", Dokuz Eylül Üniversitesi İlahiyat Fakültesi Dergisi, S: 6, s. 391-403.

Türcan, Talip (2000) "İslam Hukukundaki Muhâyee ve Türk Hukukundaki Devre Mülk Kurumları Arasında Bir Mukayese", Süleyman Demirel Üniversitesi İlahiyat Fakültesi Dergisi, S: 7, s. 83-102.

Türk Hukuk Kurumu (1991) Türk Hukuk Lûgatı, 3. Baskı, Ankara, Başbakanlık Basımevi.

Türkmen, Ali (1996) İslam Eşya Hukuku, Samsun.

Yaka, Zeki (2014) "İslam Hukukunda Zilyedlik ve Mülkiyet Arasındaki Farklar”, Bülent Ecevit Üniversitesi İlahiyat Fakültesi Dergisi, C: 1, S: 2, s. 35-52.

Yıldırım, İlyas (2018) "Şüfa-Önalım Hakkı: Mecelle ve Türk Medeni Kanunun Merkezli Bir Mukayese”, İslam Hukuku Araştırmaları Dergisi, S: 31, s. 317-336.

Yıldırım, Mustafa (2012) "Vedîa", Türkiye Diyanet Vakfı İslam Ansiklopedisi, C: 42, s. 596-598.

Yılmaz, Coşkun (editör) (2008) İstanbul Kadı Sicilleri Üsküdar Mahkemesi 1 Numaralı Sicil (H. 919-927 / M. 1513-1521), C: 1, İstanbul, İSAM. 
Yılmaz, Coşkun (editör) (2011) İstanbul Kadı Sicilleri Eyüb Mahkemesi (Havâss-1 Refîa) 61 Numaralı Sicil (H. 1065-1066 / M. 1655), C: 27, İstanbul, İSAM.

Yılmaz, Coşkun (editör) (2019) İstanbul Kadı Sicilleri 52 Hasköy Mahkemesi 3 Numaralı Sicil (H. 1023-1081 / M. 1615-1670), İstanbul, İstanbul Büyükşehir Belediyesi Kültür A.Ş Yayınları.

Yılmaz, Coşkun (editör) (2019) İstanbul Kadı Sicilleri 57 İstanbul Mahkemesi 22 Numaralı Sicil (H. 1107-1108 / M. 1695-1697), İstanbul, İstanbul Büyükșehir Belediyesi Kültür A.Ş Yayınları.

Yılmaz, Coşkun (editör) (2019) İstanbul Kadı Sicilleri 60 Bab Mahkemesi 92 Numaralı Sicil (H. 1120-1121 / M. 1709), İstanbul, İstanbul Büyükşehir Belediyesi Kültür A.Ş Yayınları.

Yılmaz, Coşkun (editör) (2019) İstanbul Kadı Sicilleri 73 Bab Mahkemesi 197 Numaralı Sicil (H. 1162-1163 / M. 1749-1750), İstanbul, İstanbul Büyükşsehir Belediyesi Kültür A.Ş Yayınları.

Yılmaz, Coşkun (editör) (2019) İstanbul Kadı Sicilleri 44 İstanbul Mahkemesi 191 Numaralı Sicil (H. 1000-1027 / M. 1591-1617), İstanbul, İstanbul Büyükşehir Belediyesi Kültür A.Ş Yayınları, s. 99-100; Hüküm No: 56 [13b-1].

Yılmaz, Coşkun (editör) (2019) İstanbul Kadı Sicilleri 59 Rumeli Sadâreti Mahkemesi 161 Numaralı Sicil (H. 1115-1116 / M. 1704), İstanbul, İstanbul Büyükşehir Belediyesi Kültür A.Ş Yayınları.

Yılmaz, Coşkun (editör) (2019) İstanbul Kadı Sicilleri 79 Davud Paşa Mahkemesi 1 Numaralı Sicil (H. 1196-1197 / M. 1782-1783), İstanbul, İstanbul Büyükşehir Belediyesi Kültür A.Ş Yayınları.

Yılmaz, Coşkun (editör) (2019) İstanbul Kadı Sicilleri 90 İstanbul Mahkemesi 148 Numaralı Sicil (H. 1242 / M. 1826-1827), İstanbul, İstanbul Büyükşehir Belediyesi Kültür A.Ş Yayınları.

Yılmaz, Coşkun (editör) (2019) İstanbul Kadı Sicilleri 94 Anadolu Sadâreti Mahkemesi 2 Numaralı Sicil (H. 1251-1257 / M. 1835-1841), İstanbul, İstanbul Büyükşehir Belediyesi Kültür A.Ş Yayınları. 